\title{
AZ ALÁ-FÖLÉRENDELTSÉGI HELYZET KIEGYENLÍTÉSÉRE SZOLGÁLÓ MEGOLDÁSOK A KOLLEKTÍV MUNKAJOG ÉS A SZOCIÁLIS PÁRBESZÉD TERÜLETÉN
}

\author{
Rácz Zoltán \\ PhD, egyetemi docens, Miskolci Egyetem, Állam- és Jogtudományi Kar \\ 3515 Miskolc, Miskolc-Egyetemváros, e-mail: civracz@uni-miskolc.hu
}

\begin{abstract}
Absztrakt: A munkajogviszony egyik jellemzője a felek közötti alá-fölérendeltség. Ezen függöséget a kollektiv munkajog és a szociális párbeszéd területén több intézmény is szolgálja. Ezek közé tartozik a participáció, a sztrájk, illetve a munkaügyi biráskodás.
\end{abstract}

Kulcsszavak: kollektív munkajog, participáció, sztrájk, munkaügyi bíráskodás

Abstract: One of the characteristics of the employment relationship is the subordination of the parties. This dependence is served by several institutions in the field of collective labor law and social dialogue. These include participation, strikes, and labor justice.

Keywords: collective labor law, participation, strikes, and labor justice

\section{A gazdaságilag függő munka, illetve annak elhatárolása az önálló munkavégzéstől}

Abban egyetértés van a munkajog müvelöi körében, hogy a tradicionális munkajogviszony két markáns minősítő jeggyel írható le. Az egyik a jogviszony tartalmát meghatározó alanyi alá-fölérendeltség, a másik e jogviszony tartam jellege. A munkajogviszony tartalmát alakító alá-fölérendeltség számos kérdést vet fel, mindenekelőtt azért, mert a munkajog szerződéses jogág. (Kiss, 2020)

Annak ellenére, hogy soha nem volt jogszabály a 7001/2005. (MK 170.) FMM-PM irányelv, és már formálisan sincs hatályban, mégis az összes munkajoggal foglalkozó bíró asztalán megtalálható ez a jogi norma és mélyen beleívódott a bírói gyakorlatba. Gyulavári Tamás álláspontja szerint az eddigi bírói gyakorlattal összhangban továbbra is szükség van a munkaviszony minősítő jegyeinek meghatározására, ő javasolta az elsődleges és másodlagos minősítő jegyek megkülönböztetését. Véleménye szerint ugyanis a jegyek ilyen rendszerezése segíti az egyes ismérvek súlyának meghatározását, de az ismérvek együttes értékelése segít elkerülni a súlyozásból óhatatlanul eredő problémákat. (Gyulavári, 2014)

A minősítő jegyek esetjogra épülő korábbi rendszerét részben megváltoztatva az alábbi elsődleges ismérvek használatát javasoljuk: a) alá-fölérendeltségi viszony, széles körü munkáltatói irányítási, utasítási és ellenőrzési jog; b) személyes munkavégzési kötelezettség; c) munkabér fizetése; d) a munkakörként meghatározott feladatok rendszeres elvégzése; e) a munkáltató foglalkoztatási, a munkavállaló rendelkezésre állási kötelezettsége. Ehhez képest a másodlagos minősítő jegyek: a) a munkaidő meghatározása; b) a munkavégzés helye; c) a munkáltató munkaeszközeinek és nyersanyagainak felhasználása; d) a biztonságos, egészséges munkavégzés feltételeinek biztosítása. A Kúria egyik nemrégiben közölt határozata szerint amennyiben a megbízási jogviszony alapján a munkát végző személynek a tevékenységét alá- fölérendeltségi viszonyban, utasítások szerint, kötelezően megállapított 4 órás rendelkezésre állás és személyes közremüködés mellett kellett elvégeznie, foglalkoztatása ténylegesen munkaviszony keretében valósult meg. 
A régi Mt. 75/A. § (1)-(2) bekezdései, valamint az együttes irányelv szerinti úgynevezett minősítő jegyek alapján kellett vizsgálni, hogy a felek között ténylegesen megbízási jogviszony vagy munkaviszony jött-e létre. A munkaviszonynak az egyéb jogviszonytól való elhatárolása szempontjából elsődlegesen kellett értékelni a munkavégzés önálló vagy önállótlan, függő jellegét, az alá-, fölérendeltség fennálltát, amely a munkáltató széleskörü (a munkaviszony helyére, idejére, módjára is kiterjedő) utasítási jogában nyilvánul meg. Lényeges ismérv a munkavégzés rendszeressége és a díjfizetés jellege, továbbá a munkaviszony megállapíthatóságánál a személyes teljesítés kötelezettsége. A munkaviszonyra jellemző alá-, fölérendeltség és függőség fennállása esetén a jogviszony nem minősíthető megbízási jogviszonynak, azt a szerződő felek akarata sem vonhatja ki a munkajog szabályai alól (677.EH). (Kúria, 2019)

\section{A participáció, mint az alá-fölérendeltségi helyzet kiegyenlítésére szolgáló intézmény}

\subsection{A munkavállalói részvétel értelmezése}

A munkavállalói részvételnek többféle értelmezése is létezik a szakirodalomban. A részvétel alapvetően a munkavállalóknak a munkáltató, mint munkaszervezetet müködtető jogi személy irányításába, vezetésébe való bevonását jelenti, azaz egy aktív, együttműködő magatartást tételez fel a munkavállalók részéről. A másik oldalról a munkáltató hosszú távú együttműködésre hajlandó a munkavállalókkal, a közös érdekek felismerésével még tulajdonosi pozícióban is hajlandó a tulajdona feletti rendelkezés bizonyos korlátozására, sőt a munkavállalói döntések munkavállalókkal való megosztására. A participáció előnye az ún. munkabéke feltételeinek megteremtése (a nyomásgyakorló eszközökről történő lemondás), a munkáltató, mint szervezet eredményességének a biztosítása, illetve a munkabéke hatása által biztosított többleteredmény elérése (amelynek felosztására a munkáltató/tulajdonos és a munkavállalók megállapodást köthetnek). A participáció annak köszönheti létét, hogy a kollektív munkajog fejlődése során felmerült az igény a munkáltatói hatalom belülről történő valamilyen szintü befolyásolására. (Kiss, 2010) A munkáltató oldaláról vizsgálva a kérdést eléggé nyilvánvaló, hogy a teljes munkavállalói kollektívát megillető jogok biztosítása a szakszervezeti jogok bizonyos fokú ellentételezésére szolgált. Kiss György professzor kifejtette, hogy a szakszervezeteknek a munkaszervezeten kívülre történő szorítása kiváltotta azt a lehetőséget, hogy a nagyobb befolyással rendelkező munkáltatói szervezetek a velük azonos súlyú szakszervezeti szövetségekkel ágazati vagy országos kollektív szerződéseket tudtak kötni, amelyek kiterjesztő hatályuknál fogva kötelezővé váltak az egyes munkáltatókra. Ennek a folyamatnak a befolyásolására az ágazati/országos kollektív szerződések megkötése okán az egyes munkáltatóknak már nem volt lehetősége. A munkáltatók részéről a természetes reakció az volt, hogy munkaszervezeten belül tettek lehetővé munkavállalói koalíciókat, amelyekkel meg tudták kötni a saját kompromisszumos megállapodásaikat. Ez vezetett a kollektív munkajog duális struktúrájához. (Kiss, 2010) Az egycsatornás szisztéma lényege, hogy a munkavállalók munkahelyi szintű képviseleti intézményei a felek közötti konszenzuson alapulnak, amelyek a szakszervezetet jogosítják fel a participációs jogok gyakorlására, vagyis a participáció megvalósítója a munkahelyi szintü szakszervezet, vagy munkahelyi szinten nem müködik szakszervezet, de létezik önálló részvételi forma (jellemzően az üzemi tanács), amely munkahelyi szinten ellátja a munkavállalók képviseletét. A kétcsatornás szisztéma esetében a munkáltató minden munkavállalóját egy, a szakszervezettöl függetlenül tevékenykedö választott szervezet képviseli (általában ezt is üzemi tanácsnak nevezik). Tehát ebben a konstrukcióban egymás mellett létezik munkahelyi szinten az önálló részvételi intézmény, valamint a kollektív alkut megtestesítő szakszervezeti képviselet. A monolit 
modellre példaként az Egyesült Királyságot, Írországot, Olaszországot, USA-t és Kanadát említhetjük, míg a duális modell Németországban és Ausztriában érvényesül. (Tóth, 2008)

\subsection{A participáció kiterjesztő értelmezése}

A participáció látszólag túllép a kollektív munkajog, sőt a munkajog keretein is, hiszen a kereskedelmi (társasági), a pénzügyi jog, illetve a munkavédelmi jog területére lép, de valójában szoros az összefüggése a kollektív munkajoggal. (Tóth, 2008)

A gazdasági társaságok felügyelö-bizottságaiban lehetőség van az ún. dolgozói részvételre, vagyis ott, ahol a jogszabály kötelező elöírásánál fogva, vagy a társaság önálló döntése folytán müködik felügyelö-bizottság, ezen testületben részt vegyenek bizonyos arányban a társaság munkaszervezetében tevékenykedők is. A felügyelö-bizottságok funkciója nem a társaság irányítása, hanem elsősorban a társaság müködésének az ellenőrzése. (Sárközi, 2007) A dolgozói felügyelö-bizottsági tag teljes joggal vehet részt a társaság ellenőrzésében, így korlátok nélkül fejtheti ki tevékenységét, szavazati joga egyenértékű a felügyelö-bizottság többi tagjáéval. A felügyelö-bizottság ülésein szerzett információk egy része ugyan üzleti titoknak minősülhet, de ettől függetlenül a munkavállalói képviselő köteles tájékoztatni az őt megválasztó és felügyelő-bizottságba küldő munkavállalókat a testület ülésein elhangzottakról. Szerepe tehát elsődlegesen az, hogy a munkáltató tevékenységét megvalósító munkavállalók ismeretekhez jussanak a munkáltató múködéséről, illetve bizonyos kérdésekben akár befolyásolhassák is azt a munkavállalói képviselő személye révén.

A pénzügyi participáció eszköze a munkavállalói tulajdonszerzés biztosítása, azaz dolgozói részvények, illetve üzletrészek megszerzésének lehetősége. Ebben az esetben egymással szorosan összefonódik a munkavállalói, illetve a tulajdonosi részvétel. A pénzügyi participáció alapja, hogy a munkaszervezetben dolgozó munkavállalók ne csupán munkaerejüket kifejtve álljanak kapcsolatban a munkáltatóval, hanem tulajdonosi érdekeltségüknél fogva szorosabban is kötődjenek a munkáltatóhoz, mint munkaszervezetet kialakító és irányító jogi személyhez. Magyarországon ennek jogilag szabályozott formája a Munkavállalói Résztulajdonosi Program (1992. évi XLIV. tv.), amely a Magyarországon bejegyzett részvénytársaság vagy korlátolt felelősségü társaság részvényeinek, üzletrészeinek a társasággal munkaviszonyban álló személyek számára történő kedvezményes megszerzését teszi lehetővé. Az Európai Unióban az 1990-es évek elejétől folyik kutatás a munkavállalói pénzügyi részvételről, a korábban hatályos 77/91/EEC Direktíva többféle lehetőséget tett lehetővé a munkavállalók pénzügyi jellegü szerepvállalása tekintetében (az Irányelvet hatályon kívül helyezte a 2012/30/EU Irányelv).

A harmadik nagy terület, ahol beszélhetünk a munkavállalói részvételi jogokról, a munkavédelem területe. A magyar szabályozás egyik legnagyobb hibája, hogy a munkavédelmi participációs jogokat kizárólag a munkavédelemröl szóló 1993. évi XCIII. törvényben biztosítja. Szemben a fejlettebb európai államok gyakorlatával -, ahol az üzemi tanács közvetlenül gyakorolhatja jogait munkavédelmi kérdésekben -, Magyarországon csak közvetve beszélhetünk az üzemi tanácsnak ilyen irányú jogosítványairól (pl. a munkavédelmi szabály tervezetének véleményeztetése, vagy az üzemi tanács tájékoztatáskérési joga gazdasági és szociális kérdésekben, így munkavédelmi kérdésekben is, stb.).

\subsection{A munkavállalói képviselők és jogállásuk}

\subsubsection{A munkavállalói képviselö fogalma}

A magyar munkajog a munkavállalói képviselő fogalmát a következőképpen fogalmazza meg: „az üzemi tanács tagja, üzemi megbízott, a gazdasági társaság felügyelö bizottságának munkavállalói 
képviselője, ...” (Munka törvénykönyve 294. § (1) e) pont). Az üzemi tanács tagjairól az Mt. 235-266. §-ai, az üzemi megbízottról a 269. § rendelkezik. A gazdasági társaság felügyelő bizottságának munkavállalói képviselőjéről az új Ptk. 3:124-128. §-ai tartalmaznak szabályokat azzal, hogy a Ptk. ezen munkavállalókat „munkavállalói küldötteknek” nevezi. Az Mt. 294. § (1) bek. e) pont nem tesz még utalást sem két munkavállalói körről, a munkavédelmi képviselőről, illetve az európai üzemi tanács (euüt) tagjáról. A munkavédelemről szóló 1993. évi XCIII. törvény (Munkavéd. tv.) 87. § 6/A. pontja a munkavédelmi képviselő fogalmát akként határozza meg, hogy az „olyan, a munkavállalók által választott személy, aki a munkáltatóval való együttmüködés során képviseli az egészséget nem veszélyeztető és biztonságos munkavégzéssel összefüggő munkavállalói jogokat és érdekeket”. Az európai üzemi tanács létrehozásáról, illetve a munkavállalók tájékoztatását és a velük való konzultációt szolgáló eljárás kialakításáról szóló 2013. évi XXI. törvény (Eüt. tv.) 9-22. §-ai tartalmazzák az európai üzemi tanács tagjainak munkajogi szabályait.

\subsubsection{A munkavállalói képviselöre vonatkozó szabályozás nemzetközi háttere}

A munkavállalói képviselőkről több ILO egyezmény és hozzájuk kapcsolódó ajánlás született, amelyeket az alábbiak szerint ismertetünk.

1) Magyarország a 2000. évi LXXV. törvénnyel hirdette ki a munkavállalók biztonságáról, egészségéről és a munkakörnyezetről szóló, a Nemzetközi Munkaügyi Konferencia 1981. évi 67. ülésszakán elfogadott 155. számú Egyezményt.

Az Egyezmény 2. cikkének értelmében az Egyezmény mindazokra a munkavállalókra alkalmazandó, akik a gazdasági tevékenységnek azokban az ágazataiban dolgoznak, amelyekre az Egyezmény kiterjed.

Az Egyezmény II. Rész 4. cikk szerint „Minden tagállam köteles az országos körülmények és gyakorlat tükrében, valamint a munkaadói és a munkavállalói legreprezentatívabb érdekképviseleti szervezetekkel lefolytatott konzultáció után kialakítani, megvalósítani, és időközönként felülvizsgálni a munkavállalók biztonságára, egészségére és a munkakörnyezetre vonatkozó nemzeti politikáját. Ennek a politikának az a célja, hogy megelőzze azokat a baleseteket és egészségi ártalmakat, amelyek a munkából erednek, a munkához kapcsolódnak, vagy a munka során következnek be, azáltal, hogy minimumra csökkenti a munkakörnyezetből eredő kockázatok okait, abban a mértékben, amelyben ez a gyakorlatban észszerüen megvalósítható."

Az Egyezmény II. Rész 5. cikke kiemeli, hogy a nemzeti politikának tekintettel kell lennie a munkavállalók és képviselöik védelmére minden olyan fegyelmi intézkedéssel szemben, ami azoknak a cselekményeknek a következménye, amelyeket az ezen Egyezmény 4. cikkében foglalt politikával összhangban jogosan fejtettek ki.

Az Egyezmény IV. Része 19. cikke a munkáltatók szintjén előírja, hogy „Intézkedéseket kell foganatosítani vállalati szinten, amelyek szerint:

(a) a munkavállalók munkájuk keretében müködjenek közre a munkaadókra háruló kötelezettségek teljesítésében,

(b) a munkavállalók képviselői az üzemekben müködjenek együtt a munkaadókkal a munkahelyi biztonság és a munkaegészségügy területén,

(c) a munkavállalók képviselői az üzemekben kapjanak elégséges információt a munkaadóktól a munkahelyi biztonság és a munkavállalók egészségének biztosítására tett intézkedésekről; kikérhetik képviseleti szervezeteik véleményét ezekről az információkról, feltéve, hogy nem tárnak fel kereskedelmi titkokat,

(d) a munkavállalókat és képviselőiket az üzemben megfelelő képzésben kell részesíteni a munkavállalók biztonsága és a munkaegészségügy tekintetében, 
(e) munkavállalókat vagy képviselöiket és adott esetben az érdekképviseleti szerveket a nemzeti jogszabályokkal és gyakorlattal összhangban fel kell hatalmazni arra, hogy megvizsgálják a munkájukhoz kapcsolódó valamennyi biztonsági és egészségügyi kérdést, és a munkaadóknak ki kell ezzel kapcsolatosan kérniük véleményüket; e célból, kölcsönös megállapodás alapján, igénybe lehet venni üzemen kívüli szakértőket is."

2) Magyarország a 2000. évi LXVII. törvénnyel hirdette ki a munkavállalók üzemi képviselöinek védelméről és kedvezményeiről szóló, a Nemzetközi Munkaügyi Konferencia 1971. évi 56. ülésszakán elfogadott 135. számú Egyezményt.

Az Egyezmény 1. cikke szerint „A munkavállalók üzemi képviselőit hatékony védelemben kell részesíteni minden hátrányos intézkedés ellen, beleértve a felmondást is, amelynek indoka az érintett munkavállaló üzemi képviselői minősége vagy ilyen jellegü tevékenysége, szakszervezeti tagsága, vagy részvétele a szakszervezet tevékenységében, feltéve, hogy tevékenységük összhangban van a hatályos jogszabályokkal, kollektív szerződésekkel vagy egyéb, együttesen kialakított megállapodásokkal.”

Az Egyezmény 3. cikke meghatározza a munkavállalók üzemi képviselőinek a fogalmát, akik az alábbi munkavállalókat foglalják magukba:

„, (a) szakszervezeti képviselők, azaz a szakszervezetek, vagy a szakszervezeti tagok által kinevezett, vagy megválasztott képviselök; illetve

(b) választott képviselők, azaz az üzem munkavállalói által a nemzeti jogalkotás, vagy kollektív szerződések rendelkezéseinek megfelelően szabadon választott olyan képviselők, akiknek tevékenysége nem terjed ki olyan ténykedésekre, amelyeket az adott országban a szakszervezetek kizárólagos előjogának tekintenek."

3) Az ILO a 135. sz. Egyezmény elfogadásával azonos napon javaslatot is elfogadott 143. sz. Ajánlás formájában.

Az Ajánlás szempontjából a munkavállalói képviselők fogalma lényegében megegyezik a 135. Egyezményben foglalt definícióval.

A munkavállalói képviselők védelme körében az Ajánlás előírja, hogy „a munkavállalók képviselői részesüljenek a vállalkozásban megfelelő védelemben bármely, velük szemben alkalmazott hátrányos tartalmú cselekedettel szemben, beleértve az elbocsátást, mely munkavállalói képviselői vagy szakszervezeti tagi jogállásukon vagy tevékenységükön, illetve szakszervezeti tevékenységekben való részvételükön alapszik, eladdig, míg a hatályos törvényekkel vagy kollektív szerződésekkel, illetve kölcsönösen jóváhagyott megállapodásokkal összhangban cselekszenek."

Az Ajánlás kiterjeszti a védelmet ,azon munkavállalókra is, akik a munkavállalói képviselőválasztás vagy a kinevezés céljára alkalmazott megfelelő eljárások eredményeként már jelöltek lettek vagy e tisztségre jelölték őket. Ugyanezen védelem megadható azon munkavállalóknak is, akiknek munkavállalói képviselői jogállása megszünt. Azon időszakot, mely alatt ezen védelem megilleti a jelen bekezdésben említett személyeket, a jelen Ajánlás 1. bekezdésében említett megvalósítási módszerek segítségével lehet meghatározni."

$\mathrm{Az}$ Ajánlás részletesen felsorolja, hogy a munkavállalói képviselőknek milyen jogokat kell biztosítani a feladataik ellátása során.

Az ILO egyezményeken és ajánláson kívül a közösségi szintủ vállalkozások és vállalkozás-csoportok munkavállalóinak tájékoztatása és a velük folytatott konzultációról szóló 2009/38 EGK irányelv tartalmaz rendelkezéseket a munkavállalói képviselökröl.

\subsubsection{Az intézmény szabályozásával kapcsolatos észrevételek, javaslatok}

A jogirodalomban megjelentek olyan vélemények, hogy az Mt. jelentősen szükítette a munkavédelmi képviselők védelmét. (Somlai, 2013) Egyrészről amiatt, hogy a munkavédelmi képviselő védelme a 
szakszervezeti tisztségviselő védelméhez igazodik (ahogy azt már fentebb kifejtettük), a védelem az Mt. új 273. § (2)-(4) bekezdése alapján már csak az ún. kijelölt tisztségviselöre vonatkozik, ami a munkavédelmi képviselők esetében teljesen indokolatlan korlátozást eredményez. Ugyanez a megszorítás érvényesül a munkaszerződéstől eltérő foglalkoztatás munkáltató részéről történő alkalmazása esetén is. A munkavédelmi képviselő védelmének terjedelmi csökkentését okozza az Mt. 273. § (1) bekezdésének 2 . fordulata, amelynek értelmében a védelem csak a munkaviszony megszünést követő 6 hónapra áll fenn és csak akkor, ha az érintett a tisztséget 12 hónapon át betöltötte (a korábbi Mt-ben a két időtartam épp fordítva volt).

A gyakorlatban felmerült az a lehetőség, hogy a védelmi szabályok korlátozása következtében a szakszervezeteknek a mozgástere kiterjed arra, hogy tárgyalást folytasson a munkáltatóval, mely szervezeti egységet tekinthetik önállónak, ezáltal a védett tisztségviselők körét bővíteni lehet, ami adott esetben kollektív szerződéses szabályozást igényel. (Kártyás, 2013)

A fentieken túlmenően is lényegesen szükíti az Mt. az ÜT tisztségviselőinek munkajogi védelmét, megszünteti az ÜT tagokat megillető védelmet, így a jövőben már csak az elnököt részesíti ebben a biztosítékban. A szabályozás azért nehezen értelmezhetö, mert aki látott már müködő ÜT-t, az jól tudja, hogy az életben nem csak az ÜT elnök konfrontálódik a munkáltatóval, hanem nagyon gyakran az ÜT tagok is. Ráadásul az Mt. nem határozza meg, kik jogosultak az ÜT képviseletére, így a törvény szövegéböl nem következik, hogy arra csak az ÜT elnök jogosult. Ez is indokolja az ÜT tagok védelmének fenntartását. (Rácz, 2013)

Alapos elemzés alá vetettük a munkavállalói képviselőkre vonatkozó szabályozás nemzetközi hátterét, véleményünk szerint a jelenleg hatályos magyar szabályozás nincs teljes összhangban a Magyarország által is elfogadott nemzetközi normákkal. Egyrészröl indokolatlanul nem foglalja magában a munkavállalói képviselő fogalmába a munkavédelmi képviselőt és az euüt. tagot, másrészről nem azonos mércével méri a védelem szempontjából az összes munkavállalói képviselőt.

\subsection{Participációs jogok a munkavédelem területén}

Álláspontunk szerint a legkiterjedtebb védelmi szabályokat a kollektív munkajog területén a munkavédelemről szóló jogszabályok jelentették korábban is, és nincs ez másképp napjainkban sem.

$\mathrm{Az}$ Mvt. érdekképviselet, érdekegyeztetés fejezetszó alatt szabályozza a tulajdonképpeni munkavédelmi participációs intézményeket. Ezek közül a legáltalánosabb, de egyben legkisebb hatáskörrel rendelkezik a munkavállalókkal folytatott tanácskozás, a gyakorlatban a leghatékonyabbnak a munkavédelmi képviselő és munkavédelmi bizottság intézménye bizonyul, illetve sajátos forma a paritásos munkavédelmi testület, amelyek munkahelyi szinten tevékenykednek, míg országos hatáskörrel a Munkavédelmi Bizottság fejti ki tevékenységét, mint a nem túl nagy számú tripartit típusú érdekegyeztető fórumok egyike.

\subsubsection{A munkavállalókkal folytatott tanácskozás}

A munkáltató az egészséges és biztonságos munkavégzés érdekében köteles a munkavállalókkal, illetve munkavédelmi képviselőikkel tanácskozni, valamint biztosítani részükre a lehetőséget, hogy részt vehessenek az egészségre és biztonságra vonatkozó munkáltatói intézkedés kellő időben történő előzetes megvitatásában. (Mvt. 70. § (1) bek.) A munkavédelmi tanácskozás a törvény által tételesen felsorolt élethelyzetekben biztosítja a munkáltató döntéseibe való beleszólási lehetőséget. A törvény garanciális szabályokat nyújt a munkavállalók részére azzal, hogy a munkáltató felé elöírja a kiegyensúlyozott részvétel biztosításának kötelezettségét, munkavédelmi képviselök javaslattételi jogát és azt, hogy a munkáltató köteles ezen a fórumon ún. intézkedési jogkörrel rendelkező személy részvételét garantálni. 


\subsubsection{A munkavédelmi képviselö, a munkahelyi munkavédelmi bizottság, a paritásos munkavédelmi testület}

A törvény értelmében azoknál a munkáltatóknál kell munkavédelmi képviselöt választani, ahol a munkavállalók létszáma legalább húsz fö, ennél kevesebb létszám esetében a munkáltatónak a fentiekben ismertetett munkavédelmi tanácskozás keretében kell biztosítani a kollektív jogokat a munkavédelem területén.

A törvény meghatározza a munkavédelmi képviselői passzív választójog feltételeit, nevezetesen azt, hogy legalább 6 hónapi munkaviszonyban (az Mvt. szóhasználatában „szervezett munkavégzésre irányuló jogviszonyban") töltött idővel kell rendelkezni és a cselekvőképesség meglétét. (Az új Ptk. (2013. évi V. tv.) 2:8 §. (1) bek. értelmében minden ember cselekvőképes, akinek cselekvőképességét e törvény vagy a bíróság gondnokság alá helyezést elrendelő ítélete nem korlátozza.) A munkavédelmi képviselőket öt éves időtartamra kell választani, egyenlő, titkos és közvetlen szavazás útján. Az Mvt. nem részletezi a munkavédelmi képviselők megválasztásának, megbízatása megszünésének és müködésüknek a szabályait, hanem visszautal az mt. üzemi tanács tagságra vonatkozó szabályaira.

Munkahelyi munkavédelmi bizottságot azoknál a munkáltatóknál lehet létrehozni, ahol a munkavédelmi képviselők száma eléri a hármat, ebben az esetben a munkavédelmi képviselőt megillető jogokat ezen testület gyakorolja. Amennyiben a bizottság igényli, a munkáltató vagy hatáskörrel rendelkező megbízottja köteles megjelenni a testület ülésén (A jogszabály nem ad magyarázatot arra, mi a különbség a hatáskörrel rendelkező munkáltatói megbízott az intézkedési jogkörrel rendelkező személy között.). Álláspontunk szerint a két kategória nem fedi le egymást, az előbbi lehet gyakorlatilag bármely, a munkáltató által megbízott munkavállaló, míg az utóbbi munkavállalónak legalább az egyéb munkáltatói jogkörrel kell rendelkezni.

Végezetül lehetőség van összmunkáltatói szinten paritásos munkavédelmi testület létrehozatalára azoknál a munkáltatóknál, ahol a foglalkoztatottak száma legalább 20 fö és müködnek munkavédelmi képviselők. (Az mt. 236. § (1) bek. alapján üzemi tanács választásra akkor kerül sor, ha a munkáltatónál foglalkoztatott munkavállalók átlagos létszáma az 50 fö́t meghaladja, vagyis nincs teljes összhang a két intézmény létszám-elöírásai tekintetében.) A testület paritásos jellege azt jelenti, hogy a munkavállalók és a munkáltató azonos számban küldenek képviselőket, akik értelemszerüen csak a fentebb írt szabályok révén megválasztott munkavédelmi képviselők lehetnek. Az ilyen testületek létrehozását a munkáltatónak kell kezdeményezni, valamint biztosítani kell a szavazás lebonyolításához szükséges feltételeket, illetve a munkáltató kötelessége ezen szervezetbe delegálni vezető állású munkavállalót, és megfelelő végzettséggel rendelkező szakembert. A testület tagjainak megbízatása ugyanúgy öt évre szól, mint a munkavédelmi képviselőké. Az üzemi tanács müködésére vonatkozó mt.-beli szabályokkal összhangban írja elő az Mvt., hogy a testület müködésének feltételeit a munkáltatónak kell biztosítania. Egyébként a paritásos munkavédelmi testület sajátos müködési szabályai közé tartozik, hogy ezen szervezet elnöki tisztét felváltva gyakorolják a munkavállalók, illetve a munkáltató képviselöi.

A fenti három munkavédelmi intézmény hatásköre nem keresztezheti egymást, vagyis jogkörüket és hatáskörüket önállóan gyakorolják, felelősségük pedig szintén önálló a munkavédelmi követelmények betartása vonatkozásában.

A munkavédelmi képviselö hatáskörébe tartozik, hogy jogosult meggyőződni a munkahelyeken az egészséget nem veszélyeztető és biztonságos munkavégzés követelményeinek érvényesüléséről, így különösen

- a munkahelyek, a munkaeszközök és egyéni védőeszközök biztonságos állapotáról;

- az egészség megóvására, illetőleg a munkabalesetek és foglalkozási megbetegedések megelőzésére tett intézkedések végrehajtásáról; 
- a munkavállalóknak az egészséget nem veszélyeztető és biztonságos munkavégzésre történő felkészítéséről és felkészültségéről. (Mvt. 71. §)

A törvény a fenti hatásköri szabályokhoz kimerítő jellegü jogköröket is rendel a 72. § (2) bek. és a 73-74. §-nak megfelelően. Ennek alapján a munkavédelmi képviselő

- müködési területén a munkahelyekre munkaidőben beléphet, tájékozódhat az ott dolgozó munkavállalóktól;

- részt vehet a munkáltató azon döntései előkészítésében, amelyek hatással lehetnek a munkavállalók egészségére és biztonságára, ideértve a szakemberek elöírt foglalkoztatására ( 8 . §, 57-58. §-ok), a munkavédelmi oktatás (55. §) megtervezésére és megszervezésére, az új munkahelyek létesítésére vonatkozó döntéseket is;

- tájékoztatást kérhet a munkáltatótól minden kérdésben, amely érinti az egészséget nem veszélyeztető és biztonságos munkavégzést;

- véleményt nyilváníthat, kezdeményezheti a munkáltatónál a szükséges intézkedés megtételét;

- részt vehet a munkabalesetek kivizsgálásában, az arra jogosult kezdeményezésére közremüködhet a foglalkozási megbetegedés körülményeinek feltárásában;

- indokolt esetben a hatáskörrel rendelkező munkavédelmi hatósághoz fordulhat;

- a hatósági ellenőrzés során az ellenőrzést végző személlyel közölheti észrevételeit.

- a munkavédelmi képviselö fentiek szerinti kezdeményezésére a munkáltatónak intézkedést kell foganatosítani, vagy arra nyolc napon belül választ kell adnia,

- a munkavédelmi képviselő munkahelyi munkavédelmi program elkészítésére javaslatot tehet a munkáltató részére.

Láthatjuk, hogy a jogszabály elég széleskörü jogkörrel ruházza fel a munkavédelmi képviselőt, aki így hatáskörét hatékonyan gyakorolhatja (gyakorlati tapasztalataink azt igazolják, hogy ezen választott tisztségviselők de facto nem tudnak élni a de iure biztosított jogosítványokkal.)

Tekintettel arra, hogy a munkavédelmi képviselök tevékenységükből fakadóan napi szinten konfrontálódhatnak a munkáltatói jogkör gyakorlójával, illetve a közvetlen munkahelyi vezetőkkel, ezért indokolt az ő munkajogi védelmük szabályozása. A törvény azt a megoldást választotta, hogy az összes, fentiekben említett munkavédelmi képviselő munkajogi védelmére az mt. 273. § (1), (2) és (6) bekezdését rendeli alkalmazni, azzal az eltéréssel, hogy ezen személyek munkaviszonyának a munkáltató általi felmondással történő megszüntetéséhez, illetve velük szembeni jogkövetkezmény alkalmazásához a közvetlen felsőbb szakszervezeti szerv helyett a munkahelyi munkavédelmi bizottságot, ilyen hiányában pedig a munkavédelmi képviselő választás során létrejött választási bizottságot kell érteni, mint hozzájáruló testületet. A védelem a tisztségviselőt megbízatásának idejére és annak megszünését követő hat hónapra illeti meg, feltéve, ha a tisztségét legalább tizenkét hónapon át betöltötte.

A munkahelyi munkavédelmi bizottság, illetve a választási bizottság a munkáltatói intézkedéssel kapcsolatos álláspontját a munkáltató írásbeli tájékoztatásának átvételétől számított nyolc napon belül írásban közli. A tájékoztatásnak, ha a bizottság a tervezett intézkedéssel nem ért egyet, az egyet nem értés indokait tartalmaznia kell. Ha a bizottság véleményét a fenti határidőn belül nem közli, úgy kell tekinteni, hogy a tervezett intézkedéssel egyetért.

A munkajogi védelem szempontjából kiemelt jelentőséggel bír a 15/2016. sz. munkaügyi elvi határozat megjelöléssel közzétett eseti döntés, amely kimondta, hogy valamennyi megválasztott munkavédelmi képviselöt megilleti a munkajogi védelem. Az ügyben az új mt. hatályba lépésével a munkáltató által jogértelmezési hiányosságnak vélt helyzet miatt kellett állást foglalni a legfőbb bírói fórumnak. Elvi éllel állapította meg a Kúria, hogy a munkavédelmi képviselők régi Mt. szerinti 
munkajogi védelmére vonatkozó jogát nem lehet megvonni anélkül, hogy megállapítható lenne a korlátozásra feljogosított személyi kör, illetőleg a védelemre jogosult kiválasztásának feltételrendszere. Ellenkező értelmezés esetén kijelölés hiányában egy munkavédelmi képviselő sem élvezhetne munkajogi védelmet.

\subsubsection{Az Országos Munkavédelmi Bizottság}

A fentiekben azokat a munkavédelmi intézményeket vetettük elemzés alá, amelyek munkahelyi szinten müködnek. A Munkavédelmi Bizottság országos szinten látja el tevékenységét, a Magyarországon még müködő országos érdekegyeztetési rendszerek egyik utolsó mohikánjaként. Ezen tripartit típusú (a munkavállalók, a munkáltatói érdekképviseleti szervek és a Kormány képviselőiből álló) testület az egészséget nem veszélyeztető és biztonságos munkavégzéssel kapcsolatos országos szintủ érdekegyeztetést végzi. A Munkavédelmi Bizottság hatáskörébe tartozik

a) előzetesen véleményezni a 11. §-ban megjelölt jogszabály-koncepciók és egyéb előírások, intézkedések tervezeteit, a beszámolókat, jelentéseket és az időszakos programokat azzal, hogy egyhangú állásfoglalását vagy a tárgyaló csoportok eltérő véleményét az előterjesztéseken fel kell tüntetni;

b) részt venni a munkavédelem nemzeti politikájának, annak végrehajtását szolgáló éves intézkedési és ütemterveknek a kialakításában, értékelésében és felülvizsgálatában;

c) tárgyalni és állást foglalni, illetve ajánlást vagy véleményt kialakítani ki a tárgyaló csoportok által előterjesztett munkavédelmi kérdésekről;

d) ajánlásokat kialakítani a munkavédelemre vonatkozó szabályokban rögzítetteket meghaladó munkavédelmi követelményekröl;

e) munkájáról a közvéleményt tájékoztatni;

f) saját adataival, megállapításaival szükség szerint segíteni a munkavédelmi információs rendszer müködését;

g) dönteni a nevelés és az oktatás területén a biztonságos életvitelre, a szakmai oktatás területén az egészséget nem veszélyeztető és a biztonságos munkavégzés szabályaira vonatkozó ismeretanyag meghatározásával kapcsolatos kérdésekben.

\subsection{A nemzetközi szabályozás}

Az 1947-ben elfogadott 81. sz. Egyezményt követően az ILO 1981-ben foglalkozott a munkavállalók munkavédelmi kérdéseivel és az ülésszak elfogadta a munkavállalók munkabiztonságáról, egészségéről és a munkakörnyezetről szóló 155. sz. Egyezményt, amelyet Magyarország a 2000. évi LXXV. törvénnyel hirdetett ki. Az Egyezmény személyi hatálya az összes olyan munkavállalóra kiterjed, akik valamely gazdasági tevékenységet jelentő ágazatban dolgoznak (kivéve néhány speciális ágazatot). Az Egyezmény kiemelt hangsúlyt fektet a nemzeti szintü politikára, amelyek célja a munkából származó, vagy ahhoz kapcsolódó balesetek és egészségi ártalmak megelőzése. A dokumentum kötelezővé teszi felügyeleti rendszer kialakítását, amely ellenőrzi a munkabiztonsági szabályok betartását. Munkahelyi szinten a munkaadók kötelezettségévé kell tenni a munkabiztonsági szabályok betartását és betartatását, különös tekintettel a védőruházat és védőfelszerelés biztosítására.

A kollektív munkajog védelme kapcsán beszélhetünk belső és külső ellenőrzésről. A belső védelem a szakszervezetek és a participáció révén megvalósuló védelem. A külső védelem formái közé pedig a munkaügyi/munkavédelmi ellenőrzés tartozik, melyek megvalósulását az ILO egyezményei segítik. Magyarország ezen egyezményeket ratifikálta, konkrét érvényesülésük viszont nem mondható problémamentesnek. 


\subsection{A participációval foglalkozó Európai Uniós irányelvek}

A munkavállalói részvétel közösségi szintű szabályozásának kérdése sajátságos módon nem a szociálpolitika, illetve a kollektív munkajog területén jelent meg, hanem a kereskedelmi jog (társasági jog) egységesítésének igényével. 1970-ben az Európai Bizottság közzétette az európai részvénytársaság kialakítására vonatkozó irányelv-javaslatát, amelyben az európai üzemi tanács lett volna ezen társasági forma participációs intézménye. Ezzel egy időben egy másik elképzelés is kialakult, amelynek eredménye lett végül is az Európai Üzemi Tanácsok Irányelv létrehozatala.

1980-ban Hendrikus Vredeling holland politikus, európai parlamenti képviselő készítette el a róla elnevezett irányelv-tervezetet. Ezen jogszabály-javaslat lényege az volt, hogy a multinacionális/transznacionális munkáltatók esetében a leglényegesebb vezetői döntések nem az adott országban, hanem azon kívüli vállalati központokban születnek meg, ezért a határokon átlépö vállalkozások esetében a munkavállalók hátrányt szenvednek a munkáltatókhoz képest, mert az adott országban rendelkezésre álló ismeretek nem elegendőek a munkavállalók számára, aminek következtében a tájékoztatási és konzultációs jogaikkal hatékonyan nem tudnak élni. Vredeling véleménye szerint a fentiek következtében szükség van kógens jellegü rendelkezésekre a munkavállalók tájékoztatási és konzultációs jogainak határokon átnyúló döntései kapcsán. Az európai szociális partnerek a saját érdekeiknek megfelelően közelítettek a tervezethez, az ETUC (Európai Szakszervezeti Szövetség) üdvözölte azt, míg az UNICE (Európai Munkáltatói Szövetség) véleménye szerint fölösleges irányelv szintjén szabályozni a kérdést, elegendő egy ajánlás kiadása. A tagállamok közül az Egyesült Királyság és Dánia ellenezte az irányelv-tervezetet azzal, hogy elegendőnek tartották a kollektív megállapodások megkötését ebben a témakörben. Véleményünk szerint fordulatot egyrészről az 1989ben elfogadott Európai Szociális Karta hozott az ügyben, amely - többek között - deklarálta, miszerint a tájékoztatásnak és konzultációnak a munkavállalók irányába meg kell történnie, másrészről az 1992ben megkötött Maastrichti Szerződés, amely a szociális kérdések közé iktatta be a munkavállalóknak a munkáltató vezetésében való részvételére vonatkozó jogosultságát, így ebben a kérdésben már elég volt a korábbi egyhangú szavazás helyett az egyszerü többséggel elfogadott szavazás.

Ezen folyamatot követően 1994-ben fogadták el az európai üzemi tanácsokról szóló 94/45/EK irányelvet. (Ezzel párhuzamosan további három, ehhez az irányelvhez kapcsolódó irányelvet is elfogadtak: az Európai Részvénytársaságról szóló, az Európai Szövetkezetről szóló, és az ún. tájékoztatási irányelvet. A négy irányelvben a tájékoztatás, a konzultáció és a részvétel fogalma nincs összehangolva, a terminológiájuk elnagyolt, az időtényező szempontjából hiányosak, illetve a szabályozási struktúra indokolatlanul bonyolult. A magyar munkajogi irodalomban megjelent olyan javaslat, hogy a kiindulási pont az általános tájékoztatási irányelv legyen, a másik három irányelvben megjelenő összesen három szempont - határokon átívelő jelleg, szervezeti létszám és szervezeti forma - közül az utóbbi kettőt egységesíteni lehetne, és ebben az esetben az összes, ezer főnél több munkavállalót foglalkoztató Európai Részvénytársaság és az összes, ezer fönél több természetes személyt számláló Európai Szövetkezet esetében létre kellene hozni egy Európai üzemi tanácsot. Ez az egységesítés reálisan megszüntethetné a választott szervezeti forma miatt adódó esetleges versenyhátrányt. (Ásványi, 2013)) Az irányelv területi hatálya az EFTA országok tekintetében alkalmazandó volt, mert jogalapja a Maastrichti Szerződéshez füzött Szociálpolitikai Megállapodás volt. Az irányelv meghatározta az ellenőrző vállalkozás fogalmát, amely lényegében a konszern fogalmával azonos. Az alapvető célkitüzés volt lehetővé tenni a munkavállalók döntésekben való részvételét azokban az esetekben is, amikor a munkavállalók élet- és munkakörülményeit érintő munkáltatói döntések külföldön a közösségi szinten tevékenykedő vállalatok és vállalkozás-csoportok vezetésében 
születnek. Az irányelv megkettőzte a nemzeti jogok participációs rendszereit, mert az azokra vonatkozó szabályokat érintetlenül hagyta.

A XXI. század elejére a klasszikus participációs jogok helyett elötérbe került a munkavállalók tájékoztatási és konzultációs jogának markáns biztosítása. Ennek jegyében született meg a 2002/14-es EK irányelv, amely a mai napig meghatározó jogszabálya a kollektív munkajognak. Az irányelv személyi hatálya a meghatározott létszám fölötti munkavállalót foglalkoztató munkáltatóra terjed ki, meghatározva a munkavállalók informálásának, illetve a konzultációnak az általános szabályait (ide értve azokat a témaköröket, amelyek a tájékoztatás és konzultáció tárgyát jelentik). Lényeges elöírás, hogy az irányelvben foglaltak nem szüntetik meg a tagállamokban már meglevő, a tájékoztatást és konzultációt biztosító, a szociális partnerek által megkötött megállapodásokat, illetve az ezek alapján létrehozott intézményeket. Ez azt jelenti, hogy a participáció területén továbbra is megmarad a tagállam belső szabályozási jogköre, a nemzeti sajátosságokra tekintettel. Az irányelv tulajdonképpen egységesíti a munkavállalók tájékoztatására és a velük való konzultációra vonatkozó szabályokat kötelező jelleggel, megengedve a már fentebb említett nemzeti szintü eltérés lehetőségét.

\subsection{A hatályos Mt. participációra vonatkozó részének kritikai elemzése}

Az Mt. - a régi Mt-hez hasonlóan - nem rendezi az üzemi tanács közjogi jogállásának a kérdését. A korábbi szabályozás szerint sem volt jogi személy az üzemi tanács, és ez a megközelítés nem változott, de célszerü lett volna az új Mt-ben rendezni a jogalanyiság kérdését.

Az Mt. lényegesen egyszerüsítette az üzemi tanács választás szabályait, mellőzve a korábbi részletes és eredetileg is felesleges rendelkezéseit. Ezen részletszabályok megfogalmazása a választási bizottság hatáskörébe tartozik.

Az üzemi tanács választás és müködés költségei körében az Mt. kijelenti, hogy az ezekkel kapcsolatos indokolt költségek a munkáltatót terhelik. Az Mt. nem tartotta fenn a régi Mt. 63. §-ának azon szabályát, miszerint a költségek mértékét a munkáltató és az üzemi tanács közösen állapítja meg, vita esetén pedig egyeztetésnek volt helye. Álláspontunk szerint indokolt lett volna a korábbi szabályozás fenntartása.

Az Mt. elhagyta a régi Mt. 54. §-ában rögzített azon szabályozást, hogy a választással kapcsolatos vita esetén a felek között egyeztetést kell lefolytatni. Ehelyett a törvény 249. § értelmében a jelöléssel és választással kapcsolatos kifogások esetén a törvény szerint erre jogosultak azonnal bírósághoz fordulhatnak. Az indokolás szerint az egyeztetés mellőzésének célja az eljárás gyors befejezése. Nem érthető, hogy mennyiben hátráltatta a választás végeredményének ,jogerőssé válását” a régi Mt. 54. §ában biztosított kétszer öt napos egyeztetés lebonyolítása.

Mindenképpen helyeselni tudjuk a vállalati csoport szintü üzemi tanács szabályainak az elfogadását. Ezzel a megoldással a törvény megalkotói igyekeztek megteremteni az Mt. és az akkor hatályban volt Gt. összhangját (2006. évi IV. tv. 52-64. §-ai), és az üzemi tanács intézményét a társasági jog struktúrájához igazítani, elősegítve ezzel azt, hogy a munkavállalók valóban olyan szinten szólhassanak bele a munkáltató döntéseibe, ahol azok megszületnek.

Lényegesen szükíti az Mt. az üzemi tanács tisztségviselőinek munkajogi védelmét, megszünteti az üzemi tanács tagokat megillető védelmet, így a jövőben már csak az elnököt részesíti ebben a biztosítékban. A szabályozás azért nehezen értelmezhető, mert aki látott már müködő üzemi tanácsot, az jól tudja, hogy az életben nem csak az üzemi tanács elnök konfrontálódik a munkáltatóval, hanem nagyon gyakran az üzemi tanács tagok is. Ráadásul az Mt. nem határozza meg, kik jogosultak az üzemi tanács képviseletére, így a törvény szövegéből nem következik, hogy arra csak az üzemi tanács elnöke jogosult. Ez is indokolja az üzemi tanács tagok védelmének fenntartását. 
Az üzemi tanács müködésének normái is egyszerüsödtek, a részletszabályokat az Mt. az ügyrend megfogalmazására bízza.

$\mathrm{Az}$ üzemi tanács jogkörei tekintetében álláspontunk szerint visszalépés történt a korábbi együttdöntési, a jövőbeni közös döntési jogkört illetően, hiszen ezután már csak a jóléti célú pénzeszközök felhasználására vonatkozik e jogkör, a korábbi jóléti célú intézmények és ingatlanok hasznosítására vonatkozó döntési jogkör megszünik. Vagyis marad pl. a temetési segélyek mértékének, elosztásának tárgyában hozandó döntés, de már nem tartozik ide a korábbi vállalati üdülőből kialakított, a munkavállalók pihenését szolgáló ingatlanok bérbeadására irányuló döntés. A törvényi indokolás hozzáfüzi, hogy ez a jövőben a munkáltató mérlegelési jogkörébe tartozik.

Elhagyta az mt. a régi Mt-nek azon szabályát, hogy az üzemi tanács jogkörébe tartozó szabályok megsértésével hozott munkáltatói intézkedések érvénytelennek minősülnek. A törvényi indokolás szerint a munkáltatói intézkedések körébe rendeltetésüknél, illetve hatásuknál, súlyuknál fogva meglehetősen különböző döntések tartoztak, ezért amennyiben az üzemi tanács nem ért egyet a munkáltatói intézkedéssel, vagy a munkáltató megsértette az új mt. 264. §-át, ebben az esetben kollektív érdekvita kezdeményezhető.

Ellentmondást vélünk felfedezni az üzemi tanács tájékoztatás közzétételi jogával kapcsolatban, miután az Mt. 261. § értelmében „,a munkáltató az üzemi megállapodásban meghatározott módon biztosítja annak lehetőségét, hogy az üzemi tanács a tevékenységével kapcsolatos tájékoztatást közzétegye". Kérdésként vetődik fel, hogy amennyiben a felek nem kötnek üzemi megállapodást, ebben az esetben hogyan kell a munkáltatónak biztosítania az üzemi tanács közlemény közzétételi jogát.

Az Mt. lehetővé teszi az üzemi tanács és a munkáltató között üzemi megállapodás megkötését. A törvény értelmében kétféle üzemi megállapodás köthető, az egyik, az ún. kötelmi hatályú üzemi megállapodás, amely a munkáltató és üzemi tanács együttműködésének előmozdítására szolgál, míg a másik, az ún. normatív hatályú megállapodás, amelynek rendeltetése, hogy a kollektív szerződést meghatározott feltételek fennállása esetén, és megfelelő tartalmi korlátozással részben pótolhassa. Ez utóbbi típusú üzemi megállapodásra már volt példa a magyar munkajogban, de akkor nem váltotta be a hozzá füzött reményeket. (Kiss, 2000)

Összességében elmondhatjuk, hogy az Mt. nem váltotta be a participációs intézményeknek tulajdonított pozitív szerepet.

\section{A sztrájk, mint az alá-fölérendeltségi helyzet kiegyenlítésének „radikális” eszköze}

\subsection{A munkaküzdelem fogalma}

Sem a nemzetközi munkajog, sem a magyar kollektív munkajog nem ismer egy egységes definíciót a munkaküzdelem jogát illetően. Abban sincs egységes álláspont, hogy mely egyes cselekményeket gondolunk idetartozónak, illetve a különböző országok gyakorlata eltérö abban a tekintetben, hogy az egyes „harci cselekményeket” jogszerünek avagy jogszerütlennek ítélik meg.

Az ILO kidolgozott egy ajánlást a sztrájk fogalmára az egységes statisztikai megítélés érdekében. E definíció szerint a sztrájk a munkavállalók egy vagy több csoportja, illetve a szakszervezet által kezdeményezett, a munkavállalók közös gazdasági és szociális érdekének biztosítására szolgáló, időleges munkabeszüntetés annak érdekében, hogy a munkavállalók kikényszerítsék valamilyen követelésük teljesítését, illetve ellenállásukat fejezzék ki valamivel szemben, vagy így nyilvánítsák ki sérelmüket, esetleg más munkavállalókat támogassanak követeléseikben, vagy szolidaritást vállaljanak azokkal sérelmeikben. (Tóth, 2008) 
A magyar munkajogi szakirodalom egyik legfontosabb monográfiájának meghatározása szerint „,a sztrájk a munkavállalók többségének tervszerü és közösen végrehajtott ideiglenes munkabeszüntetése a munkajogviszony előzetes felmondása nélkül”. (Kiss, 2000)

A két definícióban azonos elem a munkavállalók többségi akarata, illetve a munkabeszüntetés időleges jellegének a hangsúlyozása. A leglényegesebb eltérés a fogalmi meghatározásban, hogy Kiss György hangsúlyt helyez arra, hogy a sztrájk esetében nem merül fel a munkaviszony megszüntetésének szándéka a munkavállalók részéről. Az ILO definíciója ugyanakkor a sztrájkjog alanyaként nemcsak a munkavállalókat, vagy azok csoportját jelöli meg, hanem a szakszervezeteket is.

A munkaadói harci cselekmények közé tartozik a munkajogviszony módosításának elutasítása miatt, ezen okra való hivatkozással történő ún. tömeges felmondás.

\subsection{A munkaküzdelem jogának külső jogi környezete}

Több nemzetközi egyezmény tartalmaz rendelkezést a kollektív fellépéshez való jogokról (ide értve a sztrájkhoz való jogot is). Az Egyesült Nemzetek Közgyülése által elfogadott - Magyarországon az 1976. évi 9. törvényerejü rendelettel kihirdetett - Gazdasági, Szociális és Kulturális Jogok Egyezségokmányának 8 . cikke szerint „Az Egyezségokmányban részes államok kötelezettséget vállalnak arra, hogy biztosítják

a) mindenkinek azt a jogát, hogy saját gazdasági és társadalmi érdekeinek előmozdítása és védelme érdekében másokkal együtt szakszervezetet alakítson, és az általa választott szakszervezetbe egyedül az adott szervezet szabályaitól függően - beléphessen. E jog gyakorlását csak a törvényben meghatározott olyan korlátozásoknak lehet alávetni, amelyek a demokratikus társadalomban az állambiztonság, a közrend, vagy mások jogai és szabadsága védelmében szükségesek;

b) a szakszervezeteknek azt a jogát, hogy országos szövetséget vagy társulást létesítsenek, valamint az utóbbiaknak azt a jogát, hogy nemzetközi szakszervezeti szervezetet alakítsanak, illetve ahhoz csatlakozzanak;

c) a szakszervezeteknek azt a jogát, hogy - eltekintve a törvényben meghatározott olyan korlátozásoktól, amelyek demokratikus társadalomban az állambiztonság, a közrend vagy mások jogai és szabadsága védelme érdekében szükségesek - szabadon müködjenek;

az adott ország törvényeivel összhangban gyakorolt sztrájkjogot."

Az Európai Szociális Charta - amelyet Magyarországon az 1999. évi C. törvény hirdetett ki - 5. cikke alapján a munkavállalókat megilleti a szervezkedési jog, amelynek értelmében a munkavállalók és a munkaadók azon szabadságának biztosítására és támogatására, hogy gazdasági és szociális érdekeik védelmében helyi, országos vagy nemzetközi szervezeteket hozhatnak létre és csatlakozhatnak ezen szervezetekhez, a szerződő felek kötelezettséget vállalnak arra, hogy a nemzeti törvények sem önmagukban, sem alkalmazásuk révén nem csorbítják ezt a szabadságot. Az 5. cikk szerint az itt írt jogoknak a rendőrség, illetve fegyveres erők vonatkozásában korlátozást írhatnak elő a tagállami jogszabályok.

A 6. cikk a béralkuhoz való jogot biztosítja a következő tartalommal. „A béralku megkötésére irányuló tárgyalások folytatására való jog tényleges gyakorlásának biztosítására a szerződő felek kötelezettséget vállalnak arra, hogy

1) támogatják a dolgozók és a munkaadó közötti konzultációt;

2) ahol szükséges és helyénvaló, ott támogatják a munkaadók vagy munkaadói szervezetek és a dolgozói szervezetek közötti önkéntes tárgyalási mechanizmusokat a munkafeltételek és körülmények kollektív szerződések általi szabályozása céljából; 
3) támogatják a munkaügyi viták rendezését szolgáló megfelelő érdekegyeztetési és önkéntes döntési mechanizmusok létrehozását és felhasználását; és elismeri

4) a dolgozók és a munkaadók jogát az érdekkonfliktusok esetén történő kollektív fellépésre, beleértve a sztrájkhoz való jogot is, azon kötelezettségek függvényében, amelyek a korábban életbe lépett kollektív szerződésböl eredhetnek."

A 2000. évi LIX. tv. - amely a kényszermunka felszámolásáról szóló, a nemzetközi munkaügyi konferencia 1957. évi 40. ülésszakán elfogadott 105. számú Egyezmény kihirdetését tartalmazza, szintén foglalkozik a sztrájkjoggal, az 1. cikk d) pontja értelmében az ENSZ minden tagállama, amely ratifikálja az Egyezményt, kötelezettséget vállal arra, hogy felszámolja a sztrájkban való részvétel büntetését.

Az Európai Unióról szóló szerződés és az Európai Közösséget létrehozó szerződést hatályba léptető 2007. évi CLXVIII. tv. 28. cikke rendelkezik a kollektív tárgyaláshoz és fellépéshez való jogról, és megállapítja, hogy a munkavállalóknak és a munkaadóknak, illetőleg szervezeteiknek az uniós joggal, valamint a nemzeti jogszabályokkal és gyakorlattal összhangban joguk van arra, hogy megfelelő szinten kollektív tárgyalásokat folytassanak és kollektív szerződést kössenek, valamint hogy érdekütközés esetén érdekeik védelmében együttesen lépjenek fel a sztrájkot is beleértve.

A Nemzetközi Munkaügyi Szervezet (ILO) keretei között elfogadott nemzetközi egyezményekben az egyesülési szabadság és a szervezkedési jog védelméről szóló, a nemzetközi munkaügyi konferencia 1948. évi 31. ülésszakán elfogadott 87. sz. egyezménye, a szervezkedési jog és a kollektív tárgyalási jog elveinek alkalmazásáról szóló, a nemzetközi munkaügyi konferencia 1949. évi 32. ülésszakán elfogadott 98. sz. egyezménye - nincsen kifejezett szabályozás a sztrájkjogról. Ugyanakkor az ILO esetjoga általánosságban elismeri a sztrájkjogot, mint a kollektív tárgyalások lefolytatásához szükséges olyan jogot, amely ezen egyezmények védelmét élvezi.

\subsection{A sztrájkjog helye az alapjogok rendszerében}

A kollektív munkajog történeti fejlődése alatt megfigyelhető, hogy a kezdetekben büntetőjogi eszközökkel kezelt munkaküzdelmi eszközök megítélése éppen akkor vált problematikussá, amikor bekövetkezett a munkajog ún. konszolidációja. (Kiss, 2010) A kollektív munkajog konszolidációja alatt pedig azt értjük, hogy a korábbi „harcos” munkajog egyre inkább a kompromisszumos megoldások jogává alakult át. Ebből pedig az következik, hogy a munkaküzdelem jogának elismerése nem teljes körü, az nagyon sok vitát váltott ki. Egyes vélemények szerint nem egyeztethetö össze a békés megoldások az építő kollektív munkajoggal, mások szerint viszont a munkaküzdelem jogának elismerése az önrendelkezés jogának a megvalósítását jelenti. (Kiss, 2010)

$\mathrm{Az}$ alapjogok tradicionális felosztása értelmében a sztrájkjog a második generációs gazdasági, szociális, kulturális jogok körébe tartozik (egyes vélemények szerint politikai, gazdasági, szociális jogok megkülönböztetés helyett helyesebb lenne a szociális szférára kiható alapvető jogok fogalom bevezetése (Kajtár, 2011)). A jogi irodalomban felmerülő álláspontok szerint (Kajtár, 2011) a sztrájkjog tulajdonképpen az egyesülési és a gyülekezési jog körében nyer alkotmányos védelmet, míg mások felfogása alapján a vélemény-nyilvánítási jog legalább annyira előfeltétele a sztrájkjognak, mint a gyülekezési jog. Az egyesülési jog mindenkit megillető alapvető politikai szabadságjog, az egyén joga, hogy akarata, véleménye, érdekei kinyilvánítása és védelme érdekében másokkal szervezetet hozzon létre, ezekhez csatlakozzon, illetve onnan kilépjen. Az egyesülési jog tehát egyrészt egyéni jellegü, hiszen minden jogalanyt megillet, másrészről kollektív is, mert csak többen, együttesen képesek azt gyakorolni. Az organikus elmélet szerint a sztrájk a szakszervezetek rendelkezésére álló kollektív jog, mert a munkavállalók azért alakítanak szakszervezeteket, hogy a munkáltatók erőfölényét képesek 
legyenek ellensúlyozni és így a sztrájk e cél elérésének az elengedhetetlen eszköze. Az egyéni elmélet szerint a sztrájk az egyéni munkavállalót, nem pedig a kollektívát (szakszervezetet) megillető jog. (Nacsa, 2010) Annak ellenére, hogy a munkavállalók együttesen, közösen lépnek fel, a sztrájkhoz való jog a munkavállalókat, mint individuumokat megillető jog. A sztrájkjog hasonlóságot mutat a gazdasági szabadságjogokhoz, miután az állam szerepe elsősorban negatív, ami azt jelenti, hogy itt az alapjogok gyakorlásának tiszteletben tartása kerül előtérbe, a pozitív kötelezettségek pedig másodlagosak ehhez képest, a sztrájkjog azonban nem valódi szabadságjog, mert eleve korlátozásokkal érvényesül, bizonyos helyzetekben teljes mértékben elvonható, célját tekintve is kötött, mert csak gazdasági és szociális érdekeket szolgálhat. A sztrájkjog fejlődése azt mutatja, hogy a klasszikus munkáltató-munkavállaló relációhoz kötött jogból egyre inkább állampolgári joggá alakul át. Más nézetek szerint a sztrájkjog (pontosabban a munkaharchoz való jog) levezethető a tradicionális, első generációs alapjogokból. (Kiss, 2010) A munkaharc a szociális jogállam egyik szükséges velejárója (Kiss, 2000), amelybe, illetve az ezzel okozott károkba azért kell belenyugodnunk, mert nem egyszer ez az utolsó esély a munka- és gazdasági, illetve szociális feltételeknek egy magasabb társadalmi és jogi szinten történő autonóm rendezésére.

A sztrájkhoz való jog valójában a kollektív alkufolyamat velejárója, mert a feleknek nemcsak kollektív szerződés kötésre nyílik lehetőségük, hanem annak el nem fogadására is. A mindenkori jogrendszer egyik fontos célja, hogy a munkajogviszonyokban az erőszakot visszaszorítsa, ezért - ahogy azt már fentebb kifejtettük - a sztrájkjog biztosítása némileg idegen a munkajog kompromisszumokra épülő rendszerében. (Kajtár, 2011) Ugyanakkor a sztrájk kétség kívül az alá-fölérendeltségi helyzetben lévők egyik legradikálisabb eszköze.

\subsection{Az Alaptörvény sztrájkjogot érintő szabályai}

Véleményünk szerint az Alaptörvény teljesen másképp ítéli meg a sztrájkjogot, mint alapjogot a korábbi Alkotmányhoz képest. Az Alaptörvény XVII. cikk (2) bekezdése alapján „Törvényben meghatározottak szerint a munkavállalóknak, munkaadóknak, valamint szervezeteiknek joguk van ahhoz, hogy egymással tárgyalást folytassanak, annak alapján kollektív szerződést kössenek, érdekeik védelmében együttesen fellépjenek, vagy munkabeszüntetést tartsanak". Ezzel az Alaptörvény jelentős mértékben átalakította a sztrájkjog tartalmát. Elsődlegesen látható, hogy megszünik a törvény kétharmados jellege, amely jelzi a szabályozási tárgy jelentőségének csökkenését. Óriási változás a jelenleg hatályos szöveghez képest, hogy az Alaptörvény szó szerinti értelmezése alapján a munkabeszüntetés a munkaügyi kapcsolatokban résztvevő mindkét felet (munkáltató és munkavállaló) megilleti, ami alkotmányi szintre emeli a munkabeszüntetés lehetőségét a munkáltató oldaláról (kizárás). Találkozunk olyan véleménnyel, amely szerint a jogalkotót nem vezérelte az Alaptörvény megfogalmazásakor a kizárás intézményének alkotmányjogba történő beépítése. (Berke, 2011) Egy ezt megerősítő másik álláspont (Jakab, 2011) szerint a jogalkotó azért nem gondolhatott a munkáltatókat megillető kizárás intézményének ezen szöveggel történő szabályozására, mert az EU Alapjogi Charta mintául szolgáló nem magyar nyelvű szövegei egyértelművé teszik, hogy itt kifejezetten a munkavállalói munkabeszüntetésről (sztrájkról) van szó, csak az ilyen jellegü munkamegtagadás részesül alkotmányos védelemben. A magunk részéről úgy gondoljuk, hogy amennyiben a jogalkotó nem kívánta a munkabeszüntetés lehetőségét a munkáltatók számára is biztosítani, úgy az Alaptörvény szövegében a korábban részleteiben ismertetett nemzetközi gyakorlatnak megfelelően kellett volna definiálni a sztrájkjogot a munkabeszüntetés fogalom használata helyett, mert így félreértésekre ad okot a normaszöveg. 


\subsection{A sztrájkjog elöírásai}

A jogszabály nem tisztázza pontosan a sztrájkjog alanyainak a körét. A „dolgozók” kifejezés eleve az ebben az időben hatályos Munka Törvénykönyve terminológiáját jelenti, a mai viszonyokra a munkavállalók kategóriáját értve alatta. Ez azt is jelenti egyben, hogy a sztrájkjog nem szakszervezeti jogosítvány, vagyis nem csupán a szakszervezetek jogosultak ennek gyakorlására. A sztrájkjog irányultságát a törvény a gazdasági és szociális érdekek biztosításában jelöli meg, amelynek tartalma az elmúlt két és fél évtized során jelentősen átalakult. A sztrájkjog alapelvei közül az önkéntességet, az együttmüködési kötelezettséget és a sztrájkjoggal való visszaélést emeli ki a jogszabály. A sztrájkjog fajtái közül kettő került be a normaszövegbe: a szolidaritási és a figyelmeztető sztrájk. Az első esetében - bár definíciót nem találunk a jogintézményre - a sztrájkolók kifejezik egyetértésüket egy már megindult sztrájk céljait illetően úgy, hogy nekik nem kell feltétlenül betartani a később ismertetésre kerülő eljárási szabályokat (ez a fajta sztrájk csak a szakszervezetek által kezdeményezhető). Figyelmeztető sztrájkot pedig a sztrájkot megelőző egyeztetés ideje alatt, egyetlen alkalommal, maximum két óra időtartamban lehet tartani. A lehülési idő kapcsán kötelező egyeztetést ír elő a törvény, a sztrájk megkezdése elötti kollektív munkaügyi vitában legfeljebb hét napon keresztül kell a vitában érintetteknek ezt lefolytatni. Az egyeztetés mellőzhető, ha az a sztrájk kezdeményezőjének fel nem róható okból nem valósult meg. A jogalkotó számolt azzal a lehetőséggel - ami a gyakorlatban többször is előfordult -, hogy nem derül ki pontosan, hogy melyik munkáltatóval szemben lépnek fel a „dolgozók”, ilyenkor a kormánynak kell kijelölni az egyeztetésben részt vevő képviselő személyét. Jogellenesnek minősül a sztrájk, ha az nem a gazdasági és szociális érdekek biztosítására irányul, a felek megsértik az együttmüködési kötelezettséget, illetve a sztrájkjoggal való visszaélés tilalmát, nem került sor a kötelező egyeztetésre, illetve sérti a még elégséges szolgáltatás biztosításának elvét. A jogellenesség tekintetében az ennek megállapításához jogi érdekkel rendelkező személy kérelmére a kérelmező székhelye (lakhelye) szerint illetékes közigazgatási és munkaügyi bíróság dönt nemperes eljárásban öt munkanapon belül, a döntéssel szemben szintén ötnapos fellebbezési jog áll rendelkezésre, mely esetében a másodfokú bíróság (törvényszék) szintén öt munkanapos határidő alatt hozza meg a jogerős határozatot. Tilos a sztrájk az igazságszolgáltatási szerveknél (bíróság, ügyészség), a magyar honvédségnél, a rendvédelmi-, rendészeti szerveknél és a polgári nemzetbiztonsági szolgálatoknál, a NAV hivatásos állományú kormánytisztviselöinél, illetve, ha a sztrájk az életet, egészséget, testi épséget vagy a környezetet közvetlenül és súlyosan veszélyeztetné, vagy elemi kár elhárítását gátolná. Korlátozott a sztrájk lehetősége az államigazgatási szervek esetében (a kormány és az érintett szakszervezetek közötti quasi ágazati kollektív szerződésben rögzített szabályok szerint). A sztrájkolóknak az olyan munkáltatók esetében, amely a lakosságot alapvetően érintő tevékenységet végez (pl. közforgalmú tömegközlekedés, távközlés, áram-, víz-, gáz-, egyéb energiaszolgáltatás), be kell tartaniuk a még elégséges szolgáltatás teljesítésének kötelezettségét. Az üzemi tanács tagjai - ebben a minőségükben - nem vehetnek részt sztrájkban. A bírósági döntésnek a súlyát az adja meg, hogy ha jogszerünek minősül a sztrájk, ebben az esetben a résztvevőket semmilyen joghátrány nem érheti, velük szemben hátrányos intézkedés nem tehető, és megilletik őket a munkaviszonyból eredő jogosultságok, de a sztrájk miatt kiesett munkaidőre díjazás nem jár részükre (kivéve, ha a szakszervezet képezett sztrájkalapot, és tőlük részesül díjazásban), a sztrájk időtartama szolgálati időnek minősül társadalombiztosítási jogosultságok szempontjából. Amennyiben a sztrájk jogellenesnek bizonyul, úgy az abban részt vevő munkavállaló munkaviszonyát azonnali hatállyal meg lehet szüntetni, illetve a sztrájk szervezői kártérítésre kötelezhetők.

A sztrájkjog tartalmának változását már elörevetítette a sztrájktörvénynek a 2010. évi CLXXVIII. törvénnyel elfogadott módosítása. A módosítás lényege, hogy a még elégséges szolgáltatás mértékét és 
feltételeit törvény állapíthatja meg. Törvényi szabályozás hiányában a sztrájkot megelőző egyeztetés során kell a még elégséges szolgáltatás mértékéről megállapodni, megegyezés hiányában a munkaügyi bíróság állapítja meg a még elégséges szolgáltatás mértékét és feltételeit. (Rácz, 2014)

\subsection{A sztrájkjog bírói gyakorlata}

A magyarországi sztrájkok bírósági megítélését alapvetően meghatározza a Kúria 1/2013. (IV.8.) KMK véleménye, amelynek rendelkező része az alábbiakat mondja ki:

„I. A sztrájkjog gyakorolhatósága tekintetében a konkrétan megfogalmazott egyes sztrájkkövetelések alapján lehet dönteni. Amennyiben valamely követelés tekintetében megállapítható, hogy az a sztrájkot kezdeményezők gazdasági és szociális érdekei biztosítására irányul és a sztrájkot a törvény kifejezetten nem tiltja, a sztrájkjog a munkavállalókat megilleti.

II/1. A még elégséges szolgáltatás mértéke és feltételei megállapítása iránti és a sztrájk jogszerüségének, illetve jogellenességének megállapítása iránti nemperes eljárás egymástól független, önálló kérelemmel kezdeményezhető. Egyik eljárás sem minősül a másik eljárás előfeltételének.

II/2. Amennyiben a kérelmező kérelme a sztrájk megtarthatósága érdekében a még elégséges szolgáltatás mértéke és feltételei megállapítására irányul, előkérdésként erre irányuló kérelem hiányában nem kell a tervezett sztrájk jogszerüségét, illetve jogellenességét vizsgálni.

II/3. A még elégséges szolgáltatás mértékéről és feltételeiről a közigazgatási és munkaügyi bíróság a felek által megtett ajánlatok mérlegelésével, az egyik fél által tett végső ajánlat elfogadásáról rendelkező határozat meghozatalával dönthet.

III. Annak megítélésekor, hogy mely tevékenység, szolgáltatás minősülhet alapvető szolgáltatásnak, a munkáltató saját vagyonvédelmén és gazdasági érdekein túlmutató, a lakosságot közvetlenül és súlyosan érintő szempontokat lehet értékelni.

A kizárólag alapvető szolgáltatásnak minősülő tevékenység végzésére új munkavállaló határozott idejű felvétele nem eredményezheti a sztrájkjog csorbítását.

IV. Amennyiben a sztrájkkövetelésben érintett munkáltató nem határozható meg, a Sztrájktörvény szerinti nemperes eljárásban kérelmezői, illetve kérelmezetti oldalon a Kormány vehet részt."

A KMK vélemény tehát iránymutatást ad a munkaügyi bírák számára a sztrájkjog fogalmának értelmezéséről, a még elégséges szolgáltatás kérdésében történő döntés kialakításának szempontjairól. Ez utóbbi kérdésben való iránymutatás azért rendkívül fontos, mert - mint azt korábban említettük - a még elégséges szolgáltatás meghatározása a bíróságok kezébe került. A gyakorlatban felmerült, hogy a szük határidők keretei közé szorított, sztrájk jogszerüségének megállapítására irányuló nemperes eljárásban mennyiben lehet szakértőt igénybe venni. A Fővárosi İtélőtábla egyik friss ítéletében (2.Mpkf.35.080/2021./5.) hivatkozik a KMK véleményre és kimondja, hogy amennyiben valamilyen szakkérdésben a felek nem tudnak megegyezni, már az egyeztető tárgyalások során vegyenek igénybe szakértőt, hiszen ez a kérdés is beletartozik a felek fokozott felelősségébe.

\section{A szociális párbeszéd}

\subsection{A szociális párbeszéd értelmezése}

A szociális párbeszéd fogalma a kezdetekben kifejezetten az Európai Unióban a szociális partnerek között zajló, különböző formában megvalósuló kapcsolatrendszert jelentette. Az évek múltával a fogalom a gyakorlatban kiterjedt egyrészről nem csupán az összeurópai szintre, hanem az Európai 
Unióban megtalálható különböző ágazatokra (ágazatok alatt az élet különbözö területeit értjük). (Ladó, Tóth, 2002)

A 2000-es évektől a szociális párbeszéd alatt már nem csupán az összeurópai vagy ágazati szinten megvalósuló, az európai szociális partnerek között zajló kapcsolatrendszert értjük, hanem a fogalom kiterjed az egyes tagállamok szintjén zajló konzultációkra, tárgyalásokra, concertation-ra, autonóm párbeszédekre. (Arató, 2001) Magyarországon a rendszerváltástól számítva a fentebb leírtak szerinti szociális párbeszéd tulajdonképpen az érdekegyeztetésnek nevezett fogalomkörben volt elhelyezhetö. Az érdekegyeztetés hazánkban a háromoldalú párbeszédet jelentette a kormány, a munkáltatói érdekképviseleti szervezetek és a munkavállalói érdekképviseleti szervezetek között. Az érdekegyeztetés legfőbb szervének elnevezése a különböző politikát folytató kormányok változásával egyidejüleg változott, de nem csupán az elnevezésnek volt jelentősége, hanem a szervezethez rendelt hatásköröknek és jogköröknek. 1992-ben az akkor hatályba lépő Munka Törvénykönyvébe is belekerült az érdekegyeztetés fogalma és legfőbb szerve, ez jelentette akkor a törvényi hátteret. A későbbi kormányok szükségesnek tartották külön, az Országos Érdekegyeztető Tanácsra vonatkozó törvény elfogadását, az időközben saját jogi szabályozást követelö Ágazati Párbeszéd Bizottságokra vonatkozó törvény hatályba léptetésével együtt. 2009-ben került sor a két önálló törvény elfogadására, a rendszerváltás utáni magyar jogtörténetben ritkán előforduló körülmények között (erről a tanulmány későbbi részében részletesen fogunk szólni).

\subsection{A társadalmi párbeszéd bizottságok szerepe és jelentősége Magyarországon}

Magyarországon a 2000-es években vita folyt az érdekegyeztetési rendszer legitimációjáról. Több éven keresztül tartott a szakmai egyeztetés (Herczog, 2008) az Érdekegyeztető Tanácsról szóló törvény elfogadása, illetve a társadalmi párbeszéd bizottságokra vonatkozó törvény megalkotása kérdésében. A hosszas előkészület után 2009-ben elfogadták a két jogszabályt, amelyeket az akkori köztársasági elnök nem írt alá, hanem alkotmánybírósági kontrollt terjesztett elö. Ezt követően az Alkotmánybíróság előtt ez az ügy az egyik leghosszabb ideig érdemi döntés nélkül maradó téma volt, amely „hallgatásnak” az okát csak vélelmezni tudjuk (mindenesetre azt tényként állapíthatjuk meg, hogy az Alkotmánybíróság sem a múltban, sem jelenleg nem rendelkezik olyan taggal, aki nem hogy a kollektív munkajognak, de egyáltalán a munkajognak igazi „specialistája lenne” (Somos, 1998)). A köztársasági elnök beadványai sikeresnek bizonyultak, hiszen mindkét elfogadott törvényről negatív ítéletet alkotott az illetékes bírói fórum, alkotmányellenesnek minősítve azokat (köztársaságunk akkori elnökének beadványai megfogalmazásában nyilván nagy segítséget nyújtott az, hogy több éven keresztül ő maga volt az Alkotmánybíróság elnöke). Ezek után a Parlament újraalkotta ezen jogszabályokat, figyelembe véve az Alkotmánybíróság jogi érveit.

Az elfogadott és azóta is hatályban levő, az ágazati párbeszéd bizottságokról és a középszintü szociális párbeszéd egyes kérdéseiről szóló 2009. évi LXXVIV. törvény elfogadásával az elemzett európai szociális párbeszéd magyarországi meghonosítására tett kísérletet hazánk.

A törvény elsődlegesen meghatározza a szociális párbeszéd szempontjából releváns fogalmakat.

A szociális párbeszéd alatt a szociális partnerek közötti kétoldalú kommunikációt érti, amely magában foglalja a rendszeres információcserét, a konzultációt, a kollektív tárgyalást, megállapodások létrehozását, közös szakpolitikák kidolgozását és megvalósítását. Ezen definíción belül tovább értelmezi a megállapodás, tárgyalás és konzultáció fogalmát. Megállapodás alatt az Ágazati Párbeszéd Bizottság (ÁPB) tagjai által elfogadott állásfoglalás, ajánlás, vagy cselekvési program, amely létrejöhet tárgyalás és konzultáció eredményeként is. A tárgyalás e törvény tekintetében az olyan egyeztetés és vita, amelynél a döntés meghozatalának jogszabályban előírt, vagy az ÁPB tagjai által előzetesen 
meghatározott feltétele a fórum (az ÁPB) egyetértése, azaz megállapodása (ilyen megállapodás szükségeltetik az egyetértési, együttdöntési, ajánlás és javaslattételi jog gyakorlásához és a kollektív szerződés megkötéséhez). A konzultáció a tárgyalással szemben a szociális párbeszéd során folytatott, tárgyalásnak nem minősülő véleménycsere, az álláspontok érdemi megvitatása, konzultáció esetén megállapodás hiányában is dönthet az arra feljogosított szerv vagy személy.

A szociális párbeszéd fent meghatározott formáit a szociális partnerek gyakorolhatják, akik alatt ezen törvény a munkáltatói és munkavállalói érdekképviseleteket, valamint az érdekképviseleti szövetséget érti. Ezen szociális partnerek hozhatják létre az Ágazati Párbeszéd Bizottságokat, amelyek a munkáltatói és a munkavállalói érdekképviseleti szervek részvételével létrejövő bipartit fórumok, amelyek a nemzetgazdaság valamelyik kisebb egységében (ágazat, alágazat, szakágazat, stb.) müködnek.

A törvény az ÁPB feladataként határozza meg az ágazat kiegyensúlyozott fejlődésének elősegítését, az ágazati szintű autonóm szociális párbeszéd megvalósítását, amelynek célja a megfelelő munkafeltételek kialakítása, a munkabéke megőrzése és a munkaerő-piaci folyamatok jogszerüségének előmozdítása.

Az ÁPB a feladatainak teljesítése érdekében különbözö jogköröket gyakorol, így az ÁPB egyes oldalai, illetve az adott oldalon tevékenykedő érdekképviseletek egymást tájékoztatják, konzultációkat folytatnak és összefoglaló nyilatkozatot adnak ki. Ezen túlmenően az ÁPB-ben az arra jogosultak kollektív szerződést és más megállapodást köthetnek, kérhetik egy kollektív szerződés ágazati szintü kiterjesztését, valamint tájékoztatást kérhetnek az ágazatban hatáskörrel rendelkező államigazgatási szervtől.

Az ÁPB törvény szigorú feltételekhez köti a taggá válásnak a lehetőségét, és egy pontrendszert állít fel az adott oldalon érdekképviseleti szervként (munkáltatói érdekképviselet vagy ágazati szakszervezet) történő müködéshez.

Ágazati Párbeszéd Bizottság létrehozását akkor lehet kezdeményezni, ha az adott ágazatban ilyen szerv még nem müködik és legalább egy ágazati munkáltatói érdekképviseleti szerv és legalább egy ágazati szakszervezet kezdeményezi annak megalakítását. Az ÁPB létrehozásáról megállapodást kell kötni az érintetteknek, amely tartalmazza a megalakításhoz szükséges legfontosabb információkat. A tényleges létrejövetelben a törvény felhatalmazást ad az ún. Ágazati Részvételt Megállapító Bizottságnak és az illetékes miniszternek (a közzététel vonatkozásában).

Az ÁPB megszünik, ha tagjai megállapodnak megszűnésében, a müködési területére tartozó valamennyi ágazatot törlik a Gazdasági Tevékenységek Egységes Ágazati Osztályozási Rendszeréből (a továbbiakban: TEÁOR), az egyik oldalon valamennyi ÁPB-tag tagsága megszűnik, vagy ha a munkáltatónál vagy munkáltatóknál foglalkoztatottak száma az ágazatban munkaviszonyban állók létszámának nyolcvan százaléka alá csökken. Az érdekképviselet ÁPB-tagsága megszünik, ha az érdekképviselet jogutód nélkül megszünik, az érdekképviselet az ÁPB-ből kilép, az érdekképviselet az adott ágazatban megszünteti érdekképviseleti tevékenységét, vagy valamely, az érdekképviseletnek minősüléshez, illetve az ÁPB-ben való részvételhez elöírt feltételnek nem felel meg.

Az Ágazati Párbeszéd Bizottságba a tagok vagy kizárólag tanácskozási joggal, vagy döntési (szavazati) joggal rendelkeznek attól függően, hogy a fentebb rögzített pontrendszer alapján milyen minősültségben részesülnek, illetve elérték-e a reprezentativitás feltételeit, ami többletjogokat biztosít számukra.

Az Ágazati Párbeszéd Bizottságokban - amint azt már fentebb jeleztük - megállapodásokat és kollektív szerződéseket köthetnek a szociális partnerek, a törvényben rögzített meghatározott feltételek esetében. Ugyancsak speciális feltételek teljesülése esetén lehetőség van az ágazati kollektív szerződés egész ágazatra történő kiterjesztésére. (A törvény végrehajtására adták ki a 22/2009. (IX.30.) SZMM 
rendeletet, amely jogszabálynak az ismertetésére és az elemzésére terjedelmi okok miatt nem keríthetünk sort.)

\subsection{A gazdasági és társadalmi párbeszéd intézménye: a Nemzeti Gazdasági és Társadalmi Tanács}

A 2010-es kormányváltást követően alapvetően megváltozott az érdekegyeztetés rendszeréről vallott korábbi felfogás. Az új kormány értelmezésében az Országos Érdekegyeztető Tanács (OÉT) csupán egy szük társadalmi réteget képviselt, a Gazdasági és Szociális Tanács, valamint a Gazdasági Érdekegyeztető Fórum párhuzamosan müködött az OÉT-tel, ráadásul nem is volt legitimációs alapja a két testületnek. Ezért tartotta szükségesnek a kormány, hogy az előbb felsorolt fórumokat egyetlen konzultatív testületbe olvassza be, amely folyamatnak a jogszabályi alapját a Nemzeti gazdasági és Társadalmi Tanácsról szóló 2011. évi XCIII. törvény képezi. A törvény részletes indoklása értelmében annak nemzetközi hátterét az uniós tagországokkal szembeni, a szociális párbeszéd fenntartására vonatkozó elvárás képezi, utalva a Római Szerződés amszterdami módosítása után, annak részévé váló, a Maastrichti Szerződéshez csatolt Szociálpolitikai Megállapodás 1. cikkére (amely szerint a tagállamoknak törekedniük kell a társadalmi partnerek közötti párbeszéd elösegítésére).

A törvény Preambuluma és indokolása szerint a törvény célja, hogy a társadalom egészét érintő általános gazdaság- és társadalompolitikai kérdéseket megvitató, konzultatív jogkörü tanácsadó testület jöjjön létre, amely javaslataival, állásfoglalásaival, elemzéseivel, véleményével segíti a kormányzati ciklusokon átívelő nemzeti stratégiák megvitatását, a harmonikus és kiegyensúlyozott gazdasági fejlődés, az ehhez illeszkedő szociális modellek kidolgozását és megvalósítását előmozdító, a gazdaságot és társadalmat érintő nemzetpolitikai irányok konzultálását.

A törvény meghatározza a személyi hatályát, miszerint az kiterjed magára a Nemzeti Gazdasági és Társadalmi Tanácsra (NGTT), valamint ezen testület kapcsán feladatot ellátó kormányzati szervekre és személyekre.

A Tanács egy többoldalú szerv, annak oldalai a gazdaság képviselőiből, az országos munkavállalói érdekképviseletekből, a civil szervezetek képviselőiből, a tudomány képviselőiből, és a bevett egyházak képviselőiből (legyenek azok hazai, vagy határon túli magyar képviselők) tevődnek össze. Az NGTT szakított az érdekegyeztetés korábbi modelljével, ami vagy bipartit vagy tripartit alapon állt össze, a résztvevő felek köre itt a hagyományos szociális partnereken kívül kiegészül a társadalom más érdekeit képviselö tagokkal.

Az NGTT a konzultációs, illetve a véleményezési és javaslattevő feladatkörében az alábbi feladatokat látja el:

- nyomon követi és elemzi az ország társadalmi-gazdasági fejlődését,

- javaslatokat dolgoz ki az Országgyülés és a Kormány részére az átfogó makrogazdasági és társadalmi problémák megoldására,

- megvitatja a foglalkoztatáspolitikai, munkaerő-piaci, a jövedelemelosztást és a társadalom széles körét érintő kormányzati stratégiákat, koncepciókat, illetve a gazdasággal, a foglalkoztatással, a jövedelmek alakulásával, a társadalompolitikával összefüggő alapvető kérdéseket,

- véleményt nyilvánít a vállalkozásokat, a foglalkoztatást, illetve a társadalom széles körét közvetlenül érintő tervezett kormányzati intézkedésekröl,

- részt vesz a jogszabályok és egyéb kormányzati döntések hatásainak feltárásában, amelyről tájékoztatja a Kormányt,

- konzultációt folytat az Európai Unióval kapcsolatos stratégiai kérdésekről, 
- megtárgyal minden olyan nemzetgazdasági vagy társadalompolitikai kérdést, amelyet a Tanács tagjainak kétharmada javaslata alapján a Tanács napirendjére tüz.

Magyarország törvényhozó és végrehajtó hatalmának vezetői felkérhetik az NGTT-t, hogy adjon állásfoglalást vagy alakítson ki véleményt az általuk fontosnak tartott kérdésekben, akik a kapott véleményt vagy javaslatot mérlegelni kötelesek.

A Tanács szervezeti felépítése kapcsán a fentiekben már utaltunk az NGTT oldalaira, de a törvény taxatíve felsorolja az egyes oldalak szereplöit. A Tanács oldalai sorában a gazdaság képviselöi között találjuk az országos munkáltatói érdekképviseletek, illetve érdek-képviseleti szövetségek elnökeit, az országos gazdasági kamarák elnökeit, a Magyarországon müködő külföldi és vegyes kamarák közös képviselőit, a társadalmi szervezetek elnökeit, akiknek feladata a gazdasággal összefüggő érdekek képviselete. A második oldalt az országos munkavállalói érdekképviseletek, illetve érdek-képviseleti szövetségek elnökei alkotják. A harmadik oldal a civil szervezetek képviselőiből áll. Az NGTT negyedik oldala a tudomány képviselöit tömöríti, ide értve az MTA elnökét és az MTA, a Magyar Rektori Konferencia és a Magyar Közgazdasági Társaság által delegált gazdaság- és társadalom- kutatót, az MTA által kijelölt, határon túli magyar tudományos élet képviselőjét. Végezetül a szintén már fentebb említett ún. bevett egyházak képviselői alkotják az NGTT utolsó oldalát.

A hagyományos szociális partnerek (szakszervezet, munkáltatói érdek-képviseleti szerv) közül nem mindenki vehet részt az NGTT munkájában, csak azok, amelyek a törvény által felállított szigorú feltételeknek megfelelnek. Jelenleg az alábbi szervezetek felelnek meg a kritériumoknak:

A) munkavállalói oldalon

- Autonóm Szakszervezetek Szövetsége (ASZSZ)

- Értelmiségi Szakszervezeti Tömörülés (ÉSZT)

- Független Szakszervezetek Demokratikus Ligája (LIGA Szakszervezetek)

- Magyar Szakszervezetek Országos Szövetsége (MSZOSZ)

- Munkástanácsok Országos Szövetsége (MOSZ)

- Szakszervezetek Együttmüködési Fóruma (SZEF)

B) munkáltatói oldalon

- Agrár Munkaadói Szövetség (AMSZ)

- Általános Fogyasztási Szövetkezetek és Kereskedelmi Társaságok Országos Szövetsége (ÁFEOSZ)

- Ipartestületek Országos Szövetsége (IPOSZ)

- Kereskedők és Vendéglátók Országos Érdekképviseleti Szövetsége (KISOSZ)

- Magyar Iparszövetség (OKISZ)

- Mezőgazdasági Szövetkezők és Termelők Országos Szövetsége (MOSZ)

- Munkaadók és Gyáriparosok Országos Szövetsége (MGYOSZ)

- Stratégiai és Közszolgáltató Társaságok Országos Szövetsége (STRATOSZ)

- Vállalkozók és Munkáltatók Országos Szövetsége (VOSZ).

- Magyar Kereskedelmi és Iparkamara

- Befektetési Tanács

- Nemzeti Agrárgazdasági Kamara

A munkáltatói és munkavállalói érdekképviseletek csak abban az esetben vehetnek részt az oldalak munkájában, ha részvételük törvényi feltételei fennállnak, amelynek igazolására hatósági bizonyítványt állítanak ki részükre.

A Tanács legfőbb szerve a plenáris ülés, ahol az oldalakon kívül állandó meghívottként tanácskozási joggal részt vesznek a miniszterek (illetve az általuk kijelölt állami vezetők). A plenáris ülésekre évente 
legalább négy alkalommal kerül sor, de annak összehívását kezdeményezheti legalább két oldal vagy a tagok legalább egyharmada. A Tanács tagjai ún. egységes oldalálláspontokat kötelesek kialakítani. A Tanács minden oldala egy szavazattal rendelkezik és a döntéseket egyszerü szótöbbséggel hozzák meg (kivéve a szervezeti és müködési szabályzat elfogadását és módosítását, amely kétharmados többséget igényel, illetve, ha az NGTT szervezeti és müködési szabályzata eltérő rendelkezést nem tartalmaz). A Tanács soros elnöke látja el a plenáris ülés összehívásával, levezetésével, képviseletével és a Tanács müködtetésével, szervezésével kapcsolatos feladatokat. A Tanács soros elnökét az oldalak képviselöi adják, a soros elnökségre az oldalak rotációja alapján kerül sor. A plenáris ülés előtt, illetve két plenáris ülés között állandó vagy meghatározott feladattal megbízott, eseti szakmai munkacsoportok müködhetnek közre.

Az NGTT operatív szerve a titkárság, amely a Tanácstól elkülönült koordinációs feladatokat ellátó szervezeti egység, feladata elősegíteni a Tanács müködésével összefüggő adminisztratív és információs feladatok ellátását és biztosítani a Tanács működésének infrastrukturális feltételeit.

\subsection{A szociális párbeszéd egyéb országos fórumai Magyarországon}

\subsubsection{A Versenyszféra és a Kormány Állandó Konzultációs Fóruma (VKF)}

A VKF-et 2012. február 22-én alakította meg a Kormány, valamint három munkavállalói és három munkáltatói érdekképviseleti szerv. Ezen testület megalakításáról szóló megállapodás szerint a versenyszférát közvetlenül meghatározó gazdasági témájú kormányzati döntések előkészítésében közremüködő tripartit konzultatív, véleményező és javaslattevő szervről van szó. A Fórum - és annak ún. Monitoring Bizottsága - jelenleg is müködő, ülésezö testület.

\subsubsection{Közszolgáltató Vállalkozások Konzultációs Fóruma (KVKF)}

2018. február 12-én alakult meg.

\subsubsection{Országos Közszolgálati Érdekegyeztetö Tanács (OKÉT)}

Az OKÉT megalakításáról a közalkalmazottak jogállásáról szóló 1992. évi XXXIII. törvény (Kjt.) rendelkezett először, de tevékenységét szabályozza a közszolgálati tisztviselők jogállásáról szóló 2011. évi CXCIX. törvény (Kttv.) és a rendvédelmi feladatokat ellátó szervek hivatásos állományának szolgálati viszonyáról 2015. évi XLII. törvény. Amint az látható, az OKÉT gyakorlatilag lefedi a közszféra összes alkalmazottjának érdekegyeztetési kérdéseit.

\subsubsection{A Közalkalmazottak Országos Munkaügyi Tanácsa (KOMT) és a Közszolgálati Érdekegyeztetö Fórum (KÉF)}

Az előzőekben felsorolt fórumokon kívül a mai napig múködik a kizárólag közalkalmazottak területén létrehozott KOMT és a közszolgálatban dolgozók érdekegyeztetési kérdéseit szabályozó KÉF.

Amíg a VKF a piaci szféra szociális kérdéseivel foglalkozó testület, addig a jelen pontban tárgyalt további testületek a közszférában tevékenykedők érdekegyeztető fórumai. A különbség az OKÉT valamint a KOMT és a KÉF között abban mutatható ki, hogy az elöbbi a közszféra valamennyi jogviszonyát együttesen érintő munkaügyi, foglalkoztatási, bér- és jövedelempolitikai kérdéseknek az országos szintủ érdekegyeztető fóruma, míg az utóbbi kettő csak speciálisan a közalkalmazottak, illetve a közszolgálati tisztviselők érdekegyeztetési lehetőségeit tárgyaló testület. (Kisgyörgy, Pásztóy, 2013)

\subsection{A szociális párbeszéd jelenlegi helyzete}


Amint azt a jelen tanulmány bevezetőjében már taglaltuk a szociális párbeszéd fogalma, szerepe és helyzete jelentős változásokon ment keresztül a 2000-es éveket követően. Az Európai Unió szabályozásával összhangban fogadta el az Országgyűlés az Ágazati Párbeszéd Bizottságokról szóló törvényt, amely az európai szociális párbeszéd magyarországi elterjesztésére tett kísérletet. Az ezzel egy időben megalkotott OÉT-röl szóló törvény viszont kérész életünek bizonyult, mert a kormányváltást követően az érdekegyeztetés korábbi rendszere helyébe az NGTT keretei között zajló társadalmi párbeszéd lépett. Ezzel megszünt a szociális partnerek és a végrehajtó hatalom között zajló szociális párbeszéd, helyette a kormány közvetlen részvétele nélküli és a szociális partnereken kívül a magyar társadalom érdekeit képviselö, különböző szervezetek bevonásával történik a „véleménycsere”.

Ezen túlmenően jelenleg Magyarországon több fóruma is van az országos szintü szociális párbeszédnek (VKF, OKÉT, KOMT, KÉF), amelyek vagy a rendszerváltás óta müködnek (müködésük szabályinak megváltoztatásával), vagy szintén a rendszerváltás óta működő szervezetek helyébe léptek, illetve a 2010-es évet követően alakultak meg. Ezen különböző fórumok müködésének esetleges összehangolására mindezidáig még kísérletek sem voltak, bár a szakirodalomban (Kisgyörgy, Pásztóy, 2014) megjelentek elképzelések egy új, a gazdasági és a közszférát lefedö ún. szuperfórum megalakítására.

Az Eszjtv. tehát létrehozta az ESZÉF megnevezésủ tripartit érdekegyeztető szervezetet, de jelen tanulmány leadása (2021. július 31.) idejében nem találtunk híradást a fórum tényleges megalakulásáról. (Az egészségügyi szolgálati jogviszonyról szóló 2020. évi C. törvény)

\section{A munkaügyi bíráskodás helyzete}

Az alá-fölérendeltség helyzet kiegyenlítésében óriási hatáskörrel rendelkeznek a bíróságok. Ezen megállapítás nem csak az individuális munkaügyi jogvitákra, hanem a kollektív munkaügyi jogvitákra is igaz (amint az ismert, a kollektív érdekviták feloldása az alternatív vitarendezés keretei között történik).

\subsection{A munkaügyi bíráskodás magyarországi története}

Egy igen rövid, 1918-as előzmény után a második világháborút követően 1973-tól létesültek elkülönült munkaügyi bíróságok Magyarországon. A rendszert elég sok kritika érte, ezért már a rendszerváltást megelözően, az 1980-as években is történtek kísérletek a munkaügyi bíróságok megszüntetésére, mert a gazdasági élet új szereplői véleménye szerint a munkaügyi bíróságok ítélkezési gyakorlata akadályozta a munkaerővel való gazdálkodást. Ezek a törekvések nem vezettek eredményre. Az első rendszerváltó kormány programjában is szerepelt a munkaügyi bíróságok megszüntetésének gondolata, de 1992-ben az akkori igazságügyi miniszter már ezen elkülönült bíróságok fontosságáról értekezett. Az új alkotmány előkészítése során is készült egy előzetes szakmai munkaanyag, amely javasolta a munkaügyi bíróságok megszüntetését, majd az 1099/1996. (X. 1.) Kormányhatározat melléklete a munkaügyi bíróságok szervezeti különállóságának megszüntetését tartalmazta. Ugyanakkor az Országgyülés a 119/1996. (XII. 31.) Ogy. sz. határozatával elfogadott egy, az alkotmány elveiről szóló koncepciót, amely az általános hatáskörü bíróságok mellett az ügyek meghatározott csoportjára külön bíróságok létesítését is megengedte. (Rácz, 2015) Tekintettel arra, hogy nem vették le a napirendről a munkaügyi bíróságok megszüntetésére vonatkozó javaslatot, ezért alakult meg (többek között) a Munkaügyi Bírák Országos Egyesülete 1997. február 3-án, amely tömörítette a munkaügyi bírákat, a munkajogi szakma pedig pártoló tagként csatlakozott a szervezethez (itt említjük meg, hogy 1993-ban a közigazgatási bírák is létrehozták saját szervezetüket, a Magyar Közigazgatási Bírák Egyesületét). Fontosnak gondoljuk 
kiemelni az Alaptörvény 25. cikk (4) bekezdése szövegének a változását is. Az eredeti szöveg szerint: „A bírósági szervezet többszintű. Az ügyek meghatározott csoportjaira - különösen a közigazgatási és munkaügyi vitákra - külön bíróságok létesíthetők.”, amely úgy változott, hogy: „A bírósági szervezet többszintü. Az ügyek meghatározott csoportjaira külön bíróságok létesíthetők.", vagyis az Alaptörvényböl kikerült a közigazgatási és munkaügyi vitákra történő utalás, (Király, Rácz, 2018) a jelenleg hatályos szöveg pedig már csupán a több szintet határozza meg.

\subsection{A munkaügyi per fogalma}

A Pp. definiálja a munkaügyi per kategóriáját, ide sorolva a Munka törvénykönyve (Mt.) alapján létesített munkaviszonyból, a közalkalmazotti jogviszonyból, a szolgálati jogviszonyból, a közfoglalkoztatási jogviszonyból, a sporttörvény alapján kötött munkaszerződéses jogviszonyból, a tanulói szerződésből eredő jogviszonyból, a hallgatói munkaszerződésből és a szociális szövetkezettel és foglalkozási szövetkezettel létesített tagi munkavégzési jogviszonyból származó pereket (külön nevesítve a kollektív munkaügyi jogviták peres eljárásban történő elbírálását, de kizárva az Mt. 289. §a szerinti nemperes eljárásban elbírált ilyen jellegü jogvitákat). Az előbbi definíciókban nem szereplö jogviszonyokból származó jogviták tehát nem minősülnek munkaügyi pernek. A korábbi szabályozáshoz képest a legjelentősebb változás, hogy a Pp. hatálya alól kikerülnek azok a jogviták, amelyek a Kp. hatálya alá tartoznak. (Wopera, 2017) A Kp. 4. §-a szerint a közigazgatási jogvita tárgya közigazgatási szerv közigazgatási jog által szabályozott, az azzal érintett jogalany jogi helyzetének megváltoztatására irányuló, vagy azt eredményező cselekményének, vagy a cselekmény elmulasztásának jogszerüsége, illetve a közszolgálati és a közigazgatási szerződéses jogviszonnyal kapcsolatos jogvita is. A Kp. 5. § (1) bekezdés értelmében pedig a bíróság a közigazgatási jogvitát közigazgatási perben bírálja el, tehát ez a közigazgatási per definíciója. 2018. január 1-jétől tehát már nem a munkaügyi bíróságok döntenek a közszolgálati jogviszonyból eredő, munkáltató és a kormánytisztviselö/köztisztviselő közötti jogvitákban.

\subsection{A munkaügyi bíróságok megszüntetésének hatása a kollektív munkajog gyakorlására}

A közigazgatási és munkaügyi bíróságok 2020. március 31. napjával megszüntek, munkaügyi bírósági ügyekben első fokon az illetékes törvényszékek, másodfokon az ítélőtáblák, míg felülvizsgálati eljárásban a Kúria jár el. A munkaügyi bíróságok individuális munkaügyi perekben jártak el elsősorban, de a kollektív munkaügyi jogvitákat is érinti a változás. Milyen változással jár a munka világára ez a körülmény? Eddig a (kollektív) munkaügyi jogvitákban az eljárást kezdeményező felek ügyében a megyeszékhelyen ítélkezö közigazgatási és munkaügyi bíróságon hoztak döntést és fellebbezés esetén az ugyanazon székhelyen található törvényszékek hozták meg a jogerös döntést. 2020. április 1-jétöl viszont csak azoknak a jogalanyoknak ,nem kell kimozdulni” a megyeszékhelyről, akik az öt magyar ítélőtábla (Budapest, Debrecen, Győr, Pécs, Szeged) székhelyén kezdeményeznek eljárást, minden egyéb esetben az igényérvényesítés akár jelentős útiköltséggel is járhat (például, ha a bíróság személyes meghallgatást tart). 


\section{Irodalom}

[1] Kiss, Gy. (2020). A foglalkoztatás rugalmassága és a munkavállalói jogállás védelme. Wolter Kluwer. Budapest.

[2] Gyulavári, T. (2014). A gazdaságilag függő munkavégzés szabályozása: Kényszer vagy lehetőség? Magyar Munkajog, 2014(1), 4-5.

[3] A Kúria Mfv.10.327/2019. sz. ítélete

[4] Kiss, Gy. (2010). Alapjogok kolliziója a munkajogban. JUSTIS Tanácsadó Bt., Pécs.

[5] Tóth, F. (2008). A munkaügyi kapcsolatok rendszere, fejlődése. Szent István Egyetemi Kiadó. Gödöllö-Budapest.

[6] Sárközi, T. (Szerk.) (2007). Társasági törvény, cégtörvény 2006-2007. HVG-ORAC. Budapest.

[7] 1992. évi XLIV. tv.

[8] Somlai, Sz. (2013). Az új Mt. vesztese: a munkavédelmi érdekképviselö. http://munkavedo.blog.hu/2013/08/02/az_uj_mt_vesztese_a_munkavedelmi_erdekkepviselet

[9] Kártyás, G. (2013). A védelem nevében - munkajogi védettség érdekképviseleti vezetöknek. http://munkajogportal.hu/a-vedelem-neveben-munkajogi-vedettseg-erdekkepviseletivezetoknek/, 2013.05.17.

[10] Rácz, Z. (2013). Az új Mt. és a munkajogi átmeneti törvény kollektív munkajogot érintő rendelkezéseiről. Publicationes Universitatis Miskolcinensis Sectio Juridica et Politica Tomus, XXXI. Miskolc University Press.

[11] Mvt. 70. § (1) bek.

[12] Mvt. 71. §

[13] Ásványi, Zs. (2013). Az Európai Üzemi Tanács - Részvétel, konzultáció és tájékoztatás az Európai Unió munkajogában. PhD dolgozat. Pécs.

[14] A gazdasági társaságokról szóló 2006. évi IV. tv. 52-64. §-ai.

[15] Kiss, Gy. (2000). Munkajog. Osiris Kiadó. Budapest.

[16] Kajtár, E. (2011). A magyar sztrájkjog értékelése a nemzetközi és európai szabályozás fényében. Kézirat. Pécs.

[17] Nacsa, B. (2010). Sztrájkjog és szabályozás. In Cs. Halmos (Ed.) Sztrájkjog Magyarországon, Complex, Budapest.

[18] Berke, Gy. megjegyzés, 2011 A magyar sztrájkjog jelene és jövöje c. konferencia, MTA Jogtudományi Intézet.

[19] Jakab, A. (2011). Az új Alaptörvény keletkezése és gyakorlati következményei. HVG-ORAC. Budapest.

[20] Rácz, Z. (2014). A munkaküzdelem helye és szerepe a kollektív munkajog rendszerében. Publicationes Universitatis Miskolcinensis Sectio Juridica et Politica, Tomus XXXII. (2014), 466-467.

[21] 2.Mpkf.35.080/2021./5.

[22] Ladó, M., Tóth, F. (2002). A szociális párbeszéd alapjai. Budapest.

[23] Arató, K. (2001). Szociális párbeszéd az Európai Unióban. Rejtjel Kiadó. Budapest.

[24] Herczog, L. (2008). A hazai érdekegyeztetés fejlődése és az ágazati párbeszéd bizottságok, avagy: az érdekegyeztetés jogi szabályozásának göröngyös útja. In Szociális párbeszéd új keretek között. Foglalkoztatási és Szociális Hivatal Társadalmi Párbeszéd Központ. Budapest.

[25] Somos, A. (1998). Alkotmánybíró-jelölés: Kényes megállapodás. Magyar Narancs, 1998/42. (X.15.), KRUG E.: Bojkottdilemma, 168 óra 13. old. 
[26] Kisgyörgy, S., Pásztóy, A. (2014). Az országos szintü szociális dialógus Magyarországon és bővitésének lehetőségei, LIGA Szakszervezetek. Norvég Projekt 2013/14. pp. 30-31. Budapest.

[27] Az egészségügyi szolgálati jogviszonyról szóló 2020. évi C. törvény

[28] Rácz, Z:: A magyar munkaügyi biráskodás ellehetetlenitésére irányuló korábbi kísérletek és a jövőbeni helyzet értékelése., 2015 A munkaügyi bíráskodás jelene és jövője - Kerekasztal konferencia, Miskolci Akadémiai Bizottság, Miskolc.

[29] Király, Cs., Rácz, Z. (2018). Gondolatok a magyar munkaügyi és közigazgatási bíráskodásról. In Bankó-Berke-Tálné (Szerk.), Quid juris? (Ünnepi kötet, pp. 215-223). Budapest-Pécs.

[30] Wopera, Zs. (szerk.) (2017). A polgári perrendtartásról szóló 2016. évi CXXX, törvény magyarázata. Wolters Kluwer. Budapest. 